\title{
'Hail and take pleasure!' Making gods present in narration through choral song and other epiphanic strategies in the Homeric Hymns to Dionysus and Apollo
}

The Homeric Hymns, a heterogeneous collection of hexametrical hymns dedicated to various gods - most dated between the 7th and 5th centuries BC, some ranging even to the Hellenistic times - are situated in the same orally-based performance tradition as the two monumental Homeric epics, the Iliad and the Odyssey. They share all the same features, especially formulaic diction set in dactylic metre and the Homeric Kunstsprache that, in synchrony, shifts between diachronic stages. Both the Hymns and the Homeric epics developed in an evolutionary process. Large-scale festivals and assemblies as occasions for seasonal re-performance, like the Panionia and later the Panathenaea in Athens, were important steps toward monumental growth through rhapsodic regularization and textual fixation between the late 9th and the 6th centuries BC. Literacy, writing technique, and alphabetic record all would have helped to produce a considerably stable transcript, while the rhapsodes re-composed in re-performances their parts taken from the whole story in a relay-arrangement according to the principles of the Lord-Parry school. These methods were refined by modern orality scholarship, narratology, and approaches combining orality with neoanalysis. ${ }^{1}$ Since Friedrich August Wolf at the end of the 18th century, the Hymns have

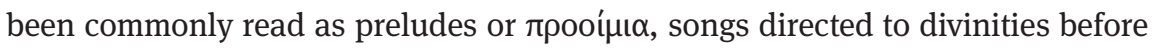
shifting to larger epic poems. ${ }^{2}$ Direct reference to the Iliad and Odyssey in the longer Hymns - those with a developed story-line - is an important component in their aesthetic appreciation. Thus we can take first steps towards intertextuality, or an awareness of a dialogical relationship between narrative traditions, regardless of the medium of the Homeric Hymn and its grade(s) of literacy. ${ }^{3}$ In-

1 On the evolutionary theory, see Nagy (1996, 2003, 2008/09, 2009/10); see the survey by Bierl (2015), esp. 186-91. On the combination of orality with neoanalysis, see Montanari, Rengakos and Tsagalis (2012).

2 Wolf (1795/1985) 112-13. See e.g. Nagy (1990a) 354-6, 359-60, (2008/09) 227-46; Petrovic (2012) 152; Faulkner (2011a) 17-18.

3 See Rengakos (2002); Tsagalis (2008, 2011).

https://doi.org/9783110559873-013 
deed, much speaks in favour of the influence of writing in some of the later Hymns.

\section{Between cult and amusement}

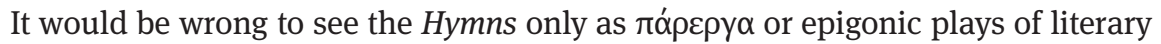
imitation. In diachronic perspective, the v̈ $\mu$ voc, or 'song', is much older than the regularized monumental epic that developed from smaller epic episodes taken from a much larger context. This type survives in the later Cyclic epic poems. ${ }^{4}$ Hymn as a communal and choral manner of praising the gods is the oldest form of lyric song, coexistent with epics over the centuries. In the Homeric Hymns hymn is standardized to a rhapsodic and regularized sub-genre of hexameter poetry performed in $\pi \alpha \rho \alpha \kappa \alpha \tau \alpha \lambda$ оупं, the recitation of reduced melody. A prior step is the kitharodic accompaniment of an ỏotós who sings a rhapsodic hymn. ${ }^{5}$ Early mythical musicians, such as Orpheus or Musaeus, perform theogonies, songs about the birth of the gods and the development of a polytheistic system, to the sound of a lyre. Hesiod's Theogony will be the model for the Homeric Hymn. The regularized monumental epic can occasionally imitate and integrate lyric, choric and, of course, theogonic-rhapsodic hymns as well as the Cyclic mode through "diachronic skewing". ${ }^{6}$ Eventually only the Iliad and the Odyssey among monumental literature will be attributed to Homer.

The Homeric Hymns are thus an interesting epic sub-genre at the intersection of several diachronic developments and production types. The Homeric Hymns can be seen as either preludes to other epic recitations, even to theogonies, or as hymns of theogonic quality in themselves, since, regarded as narrative expansions, they use to revolve around the emergence of the Olympian gods. ${ }^{7}$ But as hymns they also overlap with the basic function of cultic hymns of the communal, choral or monodic type, whose main function is to praise and summon the gods. But cultic hymns use to address the gods in the second person directly, whereas Homeric Hymns speak about them mostly in the third person. ${ }^{8}$ Only at the very end we shift to a direct a farewell address of $\chi \alpha$ ĩp $\varepsilon$ that emphasizes a reciprocal $\chi \alpha$ ápı-relation between the rhapsodic singer and the god, 'combining

4 See Nagy (2008/09) 189-98; Bierl (2012) 120.

5 See Nagy (1990a) 20-30; Bierl (2015) 186.

6 See Nagy (2003) 39-48, (2011) 305-22; Bierl (2015) 186.

7 See Furley (2011) esp. 210-18.

8 See Furley and Bremer I (2001) 41-3. 
the ideas of pleasure ("gratification") and beauty ("gracefulness") by way of reciprocity ("graciousness")'. ${ }^{9}$ The greeting means thus also a call to take pleasure.

Hymns have a clear division into three parts: the invocatio calls upon the divinity to be invoked and establishes the contact, the middle part gives a detailed praise, predicates the divinity's powers, recalls earlier benefits, describes actions and deeds in longer narrations - Ausfeld calls it the pars epica,$-{ }^{10}$ and the final prayer asks for help or for the divinity to appear. ${ }^{11}$ In the Homeric Hymns the invocation is lacking. Instead, in a very few verses, the rhapsode declares his intention to sing about the god or goddess or to remember him or her; or he summons the Muse or another deity to praise or to help him to sing about the god. The middle part in each case indeed becomes a pars epica, where the focus is on a very detailed narration about typical deeds, honours and episodes, all in the third person. In the long narrations we thus shift to the epic perspective of vivid and objective telling. The end does not provide a concrete objective of prayer, but focuses on the close and intimate relation between the god and the singer, and often declares the intention to shift to another song, or the rest of the present song. ${ }^{12}$ In short, Homeric Hymns should not be seen as purely literary hymns. The gulf between the secular and the religious, at least for archaic and classical Greek literature, has been closed and deconstructed in the last decades. ${ }^{13}$ Despite the clear focus on narration and entertaining amusement, ${ }^{14}$ the Homeric Hymns are still close to cultic hymns. The latter have been analysed as gifts or even sacrifices in order to honour the divinities through words. ${ }^{15}$ Ivana Petrovic thus emphasized the dedicatory aspect of the Homeric Hymns, their nature as private $\alpha y \alpha ́ \lambda \mu \alpha \tau \alpha$, devotional objects, and gifts to the gods. ${ }^{16}$ John F. García presented a strong argument for their symbolic function, that is, to recognize the gods via the speech act of summoning their presence through a detailed narration similar to an Anatolian historiola or other Near Eastern hymn. The story accomplishes divine presence, a function that the middle part took over in the cultic hymns. ${ }^{17}$

9 Nagy (2013a) 663. On xópıs as reciprocal relation, see Bierl (2009) 116-25, esp. 118 n. 92. 10 Ausfeld (1903) 505.

11 See Furley and Bremer I (2001) 50-63.

12 See Furley and Bremer I (2001) 41-3; Nagy (2011) 327-9.

13 See e.g. Bierl (2007a).

14 See Clay (2011) 245.

15 See Depew (2000); Calame (2011); Petrovic (2012) esp. 155-69.

16 Petrovic (2012) 155-69, esp. 156, 161-9.

17 García (2002). 


\section{The Homeric Hymns as epiphanies}

In her very influential book, The Politics of Olympus, Jenny Strauss Clay rightly stresses that the narratives of the Homeric Hymns focus on the emergence of the honours and functions of the single gods in the polytheistic system after the establishment of Zeus' order. ${ }^{18}$ Since then we are used to reading the Hymns as Panhellenic charter tales shaping the polytheistic apparatus of Olympus. In this vein, the Hymns focus on the gods in their making, envisaging them in a highly diversified political system under Zeus's rule. We could say that this amounts to the theogonic function of the Hymns. ${ }^{19}$ But this dominant view almost eclipsed the presence-assuring, ${ }^{20}$ the cultic, and the purely narrative factors. As in a kaleidoscope, we can oscillate between various aspects and functions in our reading of the Homeric Hymns: respectively, we can focus on a given Hymn's cultic worship, devotional character, creation of a valid divine order as superstructure in heaven, cathartic effect to soothe tensions by listening to magic words that tell about conflicts, crises and their solutions, or simply literary amusement with stories about gods who are all-too-human. Beyond all these very legitimate claims, we should not forget that the Homeric Hymns are hardly distinguishable from epic narration. Apart from the very small parts at the beginning and end, they look like an epic episode of the Cyclic phase. But as hymn, like the famous story of Ares and Aphrodite in Odyssey 8.266-366, it is, in diachronic terms, one more grade removed. ${ }^{21}$ The style is light and fluid, often amusing, sometimes burlesque, dealing with circular episodes of love and friendship. ${ }^{22}$

The presence of the Olympian gods is ubiquitous in Homeric epic. Constituting the superhuman apparatus, the gods watch over the action from the Olympian vantage point, while men on earth act in accordance with them and yet on their own will. In short, both sides co-act and complement each other. Gods and men are in permanent interaction and close contact with each other. Through the rhapsodic song, a historical and anthropological phase is re-actualized when gods were still in direct touch with men. Epic makes the

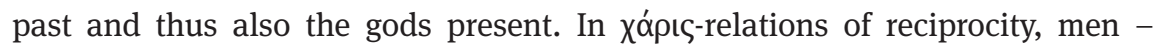

18 Clay (1989); Clay (2011) 241-4.

19 See Furley (2011) 210 -18; on the Hymns as expanding elaborations on episodes of Hesiod's Theogony, see Clay (2011) 244.

20 See Bakker (2005) 136-53; Petrovic (2012) 160-1.

21 See Nagy (2008/09) 313-42, (2009/10) 79-102; Bierl (2012) 118-21.

22 See Nagy (2008/09) 187-96, 248-76, 296-300, (2009/10) 88. 
both inside the plot and as audience outside - and gods are bound together and

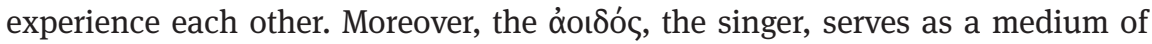
the Muses in a performance of narrative remembrance and mimetic re-enactment and re-actualization. In total empathy with the epic heroes, the audience experiences the past in the present by listening to numerous performances and reperformances. Despite the collaboration, the direct contact between men and gods remains problematic. It is a situation in limbo, since epic is situated in a period when men were already clearly separated from gods. In the Iliad and Odyssey both sides meet only occasionally and hardly directly, since human beings cannot stand in the gods' splendid radiance full of light, and are in danger of their lives being extinguished. ${ }^{23}$ Thus gods must conceal their true appearance and take on human shape. Even in these partial scenarios men can sense the divine presence through signs and react with astonishment and fear. Yet epiphanies - or at least the ambivalent allusion to and play with them - are centres of narrative energy and important highlights integrated into the monumental Homeric epic that does not focus entirely on the apparition of the god. As such, epiphanies in Homer remain notoriously vague and contradictory, as has been recently stressed by B. C. Dietrich and others. ${ }^{24}$ 'Gods are difficult to see for

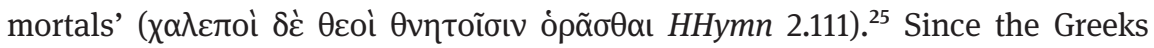
think of their gods in anthropomorphic terms, the deities can show themselves only in human disguise; as such, they are no longer real gods. Thus, anthropomorphism prevents men from imagining them in a pure and true form. Therefore

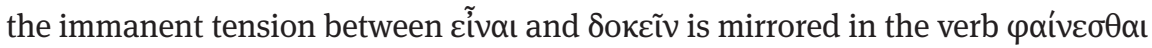

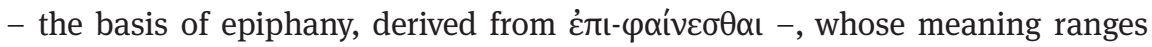
from 'to show oneself'/'appear' to 'seem as if'.

The Homeric Hymns seem to reflect the other side of the coin. Since hymns very often call for the presence of particular gods, epiphany plays a central role also in Homeric Hymns. ${ }^{26}$ Since they revolve completely around the gods, without being integrated into a carrier plot, Homeric Hymns aim at making the gods present and alive through narration. In contrast to the cultic hymns or Homeric epic, the special mnemonic capacity of the rhapsodic "I", the performer or even the author, is stressed often right in the beginning, instead of the usual invocation of the god to be praised. Furthermore, the performer only rarely asks for the in-

23 For light as a sign of epiphany, see Pfister (1924) 315-16; Richardson (1974) 208-10, 252-3; Bremer (1975) 1-12; Seaford (1996) 236 ad Ba. 1082-3; see also the literature cited in Bierl (2004) $51 \mathrm{n}$. 31. On the typical scene of Homeric epiphany in general, see Turkeltaub (2003).

24 Dietrich (1983). See also Fernández Contreras (1999); Bierl (2004).

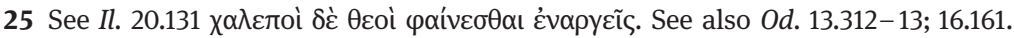

26 See Bremer (1975) 1-12; Vergados (2011) esp. the survey 82-3. 
spiration by the Muse (HHymn 4, 5, 9, 14, 17, 19, 20, 31, 32, 33). In most cases the rhapsodic or poetic "I" starts with a self-referential expression about his own

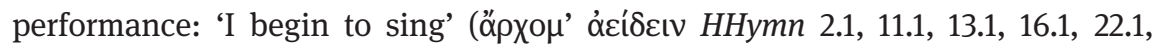
26.1, 28.1); 'I will/I am going to sing - in the sense of a performative future

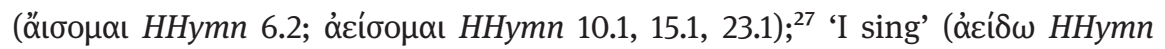
12.1, 18.1, 27.1); 'I start' - in the sense of a performative future in the subjunctive ( $\alpha \chi \chi_{\omega} \omega \alpha$ เ HHymn 25.1); 'I will remember' - again in the performative future

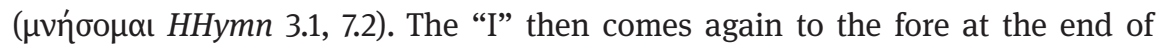
the Hymn. This is especially marked in HHymn 1.17-20, where the "I" includes the whole guild of singers and stresses Dionysus' function as god of poetic song: 'we singers sing of you as we begin and as we end a strain, and none forgetting you may call holy song to mind'. Dionysus is the origin and the inspiration for the performative process of making the god present. On the other side, any proximity to $\lambda \dot{\theta} \theta \eta$ (forgetting) results in poetic failure. At the beginning and the end of a song the rhapsodes, especially in a song about Dionysus, should mention him and get in touch with him through an act of remembrance as actu-

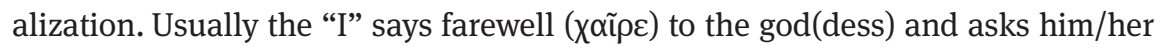
to take pleasure, establishing the xópıৎ-relation of reciprocity in song. Finally, in the very last line, the rhapsode often utters his performative intention to remem-

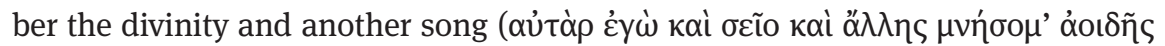
HHymn 2.495, 3.546, 4.530, 6.21, 10.6, 19.49, 28.18, 30.19; for a plural address see HHymn 25.7, 27.22, 29.14, 33.19). Or, sometimes he asks the god to lead him (äpxع

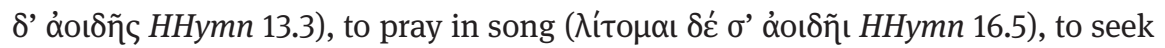

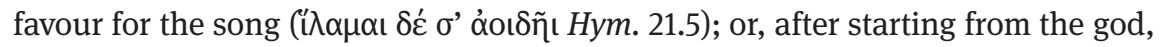

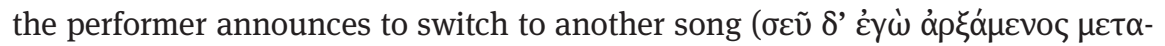

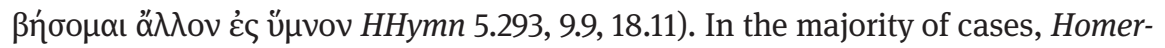
ic Hymns represent an activity of $\mu v \eta \dot{\mu \eta}$, memory. But in a still basically-oral culture, as Egbert Bakker and others have demonstrated, memory is not the process of retrieving saved information that has been archived through a written coding

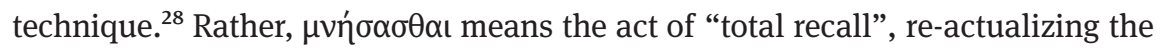
past. ${ }^{29}$ Song, $\alpha$ oเ $\delta \eta ்$, is a $\mu \nu \tilde{\eta} \mu \alpha$, or a vivid $\sigma \tilde{\eta} \mu \alpha$, a product of performance that

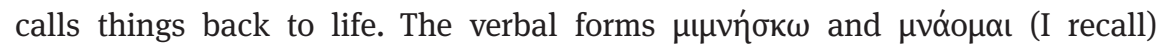
have been connected with $\mu$ ćvos (vigour, vitality, impetus, urge, active thinking). ${ }^{30}$ One may compare manas, manah in Sanskrit and the Latin animus. It is

27 On the performative future, see Bierl (2009) 294 n. 77; Calame (2011) 336 n. 9.

28 Bakker (2005) esp. 140 (with n. 14-16).

29 See Nagy (2013a) 48-50.

30 See Boisacq (1916) 625-7, 638, 641; Chantraine (1968) 658, 685, 702-3; Frisk (1970) 206-8, 238-41, 160-1; see also Bierl (2007b) esp. 49-51. 
derived from the roots ${ }^{\star} m n a$ - and ${ }^{\star} m e n$-, being present in the even more expressive verbs of mental endeavour, strife and desire. ${ }^{31}$ The exaggerated mental desire can lead to the etymologically related $\mu \alpha v i ́ \alpha$ (madness); see $\mu \alpha$ ívo $\mu \alpha$ ı (I am out of mind). ${ }^{32}$ To conclude: $\mu \mu \nu \eta \dot{\sigma \kappa \varepsilon \iota v}$ is the mental activity to call something back to life by activating it in a mental endeavour.

Therefore the Homeric Hymns to and about gods are performances designed to make them present in song and narration, to instigate the enactment of their epiphanies in immediacy and vividness. They are not explicitly called to appear, but brought to life and presence in detailed narrations that tell about their central deeds, honours, signs ( $\sigma \eta^{\prime} \mu \alpha \tau \alpha$ ), epithets and features. The hymnic performance is a speech act. By singing about remembering the god in song, the divinity becomes alive. This performative act of re-actualization is also a "mind act" and accomplishes the "presentification" as a mental activity. ${ }^{33}$ Moreover, Jean-Pierre Vernant has shown that in archaic Greece this act of memory had metaphysical underpinnings. The Greeks called to life the past not as a simple historical antecedent on a temporal axis, but as an origin and source. Thus, they remembered the past in a mythical sense as the ur-essence. They recall nature itself, the model and idea from which everything develops. ${ }^{34}$

This insight applies also for gods. Remembering the god in a setting of the past means calling to mind the deity in its metaphysical idea and original immediacy of existence from which the cosmos derives. Thus the hymns not only attempt to make the gods present but the performance re-actualizes them in their very essence and as metaphysical beings. The god "is treated" as an object observed in the perspective of the third person, but in total recall. Therefore the "I" does not normally recur to direct address in the second person, not following the usual practice of calling names, attributes, and places, of predicating powers and remembering earlier contacts and benefits. The rhapsode does not accumulate titles, explanations, amplifications either. Nor does he describe them in coincidental episodes of their curricula vitae. In the longer hymns the "I" just focuses on narratives, telling typical, formative and essential stories. The gods

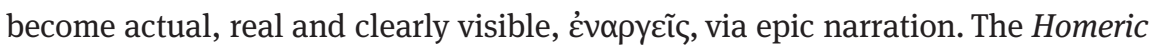
Hymns work like slow-motion epiphanies in Homeric narration. Typically the hymnic performances focus on situations where the gods' metaphysical essence

31 See $\mu \varepsilon \mu o$ ó $\omega, \mu \varepsilon v \varepsilon \alpha i ́ v \omega, \mu \varepsilon ́ \mu o v \alpha$.

32 Superseded explanations connect it to 'woman' via $\mu v \tilde{\alpha} \sigma \theta \alpha$ (to woo) and derivatives from ${ }^{\star} \mu v \alpha-<{ }^{\star} \beta v \alpha-$ 'woman' = Vedic gna- 'wife of a god'; i.e. ^guna- *gunna $\rightarrow$ yvvń; see Boisacq (1916) 641.

33 See Bakker (2005) 136-53, esp. 151.

34 Vernant (1988) 115. 
comes into being, such as stories about the birth and first deeds, arrival and first manifestation, return after retreat and crisis. The quintessential features, also expressed in epithets, are revealed in action and put into practice. Divinities can thus be grasped in a cognitive act and brought to life through song. In the act of singing, the hymn does what it narrates. The gods become accessible and real through performance. In the eyes of a given Hymn's audience or recipients, deities become alive in their essence and in their making, being summoned as gods who are part of the polytheistic system that rules the present world order. In endless chains of re-performances each rhapsodic "I" can access these formative situations of the Olympus in the making in order to get the recipient in touch with its quintessential, original and metaphysical existence. In the same way, each rhapsode reconnects to Homer, the model åoเós. After each successful narrative evocation of the deity, the singer finally gets directly in touch with him or her, establishing reciprocity in xápıc. The epic song full of grace pleases the god who has become present. In exchange for this gift the god will recompense the singer with further pleasure. Thus, in the end, the deity will somehow serve as the source of the song that, as an autonomous, creative process, first made him its subject, its theme.

As was said before, we can understand the process of remembering, enacting and revealing the essence of a god in the making through longer narration as an epiphanic act in the wider sense. Therefore, I would like to explore how epiphany, as a motif, plays an important role also within the hymns. The second Hymn to Dionysus (HHymn 7) is wholly based on the fact that this kommende Gott

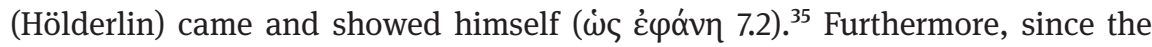
perspective of the singer is so prominent, I will look closely at how epiphany is emphasized through the self-referential integration of music, instruments, singing and dancing in monodic and choral configurations. We thus have a double constellation of a mise en abyme to bring the epiphanic aspect to the fore.

Before we go into more detail, I would like to hint at the fact that anthropomorphic blurring also plays a central role in the Homeric Hymns. One would expect greater religious clarity given the genre. But since anthropomorphism was the decisive factor for the notoriously vague treatment of epiphanies in the monumental Homeric epics, it likewise influences how gods are made to appear in the Hymns. On the one hand, we hear about the essence of the gods; on the other hand, these gods are dangerously close to mortals. They must appear in human guise to communicate with people and to achieve their objectives. Dionysus stands at the shore in the shape of a beautiful ephebe in HHymn 7, and De-

35 See Jaillard (2011). 
meter acts as a mortal woman in HHymn 2 to become the nurse of the young baby Demophon, perhaps a substitute for the loss her child Persephone. Moreover, Aphrodite plays the role of a young girl in order to have sex with a mortal herdsman, Anchises, in HHymn 5. Often people, as in the case of Anchises, sense the divine behind the disguise. ${ }^{36}$ Thus we have sometimes a subtle and amusing play between recognition and misrecognition, with the situation remaining in limbo and highly vague. Aphrodite must even recur to the lie that she is not a goddess in order to reach her goal, alleging in false fabrications that she came as a mortal girl, abducted by Hermes from the maiden choruses, to marry Anchises (HHymn 5.109-43). Since both goddesses became too human they must soon turn to partial epiphanies. ${ }^{37}$ In many longer Hymns we encounter the typified Homeric scene of gods making themselves manifest through a whole gamut of signs, such as appearing in fuller size, beaming light, glamour, radiance, etc., while mortals evince their usual reaction: trembling, fearing, wondering. ${ }^{38}$ Moreover, human instincts dominate even the Olympians. The Hymn to Aphrodite (HHymn 5) makes the goddess present by showing how her capacity to make other gods, even Zeus, fall in love with mortal humans, turns on herself. Aphrodite thus becomes alive in her essence, in her own erotic passions and sufferings. The most human of all is Hermes, the god who comes dangerously close to transgressing the boundary between gods and men. Even as a god he craves for meat. ${ }^{39}$ Thus in the longer Hymns to Aphrodite and Hermes (HHymns 5 and 4), these human - all too human - traits define the narrations. Indeed, the entire Hymn to Hermes (HHymn 4) makes this god appear in his very essence through a long epiphany, despite the absence of the typical scene of a full epiphany. ${ }^{40}$ The Hymn shows in detail how the burlesque anti-god triumphs as newly born baby in the form of a rascal and trickster. In comic distortion and in a poetics of reversal, the god becomes alive in his corporeality, trickery, wits, laughter, theft, hunger for meat and inventiveness. We even see him sacrificing and singing about and for the gods. All features speak for a very human behaviour, where the subhuman meets the supra-human and divine. ${ }^{41}$ Thus, at least in some of the longer Hymns, we encounter the following paradox: the epic hymn makes the metaphysical essence of Olympian gods present, thus coming close to the cultic dimension, while at the same time these gods are envisaged in non-divine situa-

36 See HHymn 2.159 (Callidice); HHymn 5.92-106 (Anchises).

37 See HHymn 2.185-90; HHymn 5.172-90.

38 See Turkeltaub (2003); Vergados (2011) 82-7.

39 See Versnel (2011) 319-27, 348-70.

40 See Jaillard (2007) 69-98; Vergados (2011) esp. 83-7.

41 See Versnel (2011) 309-77; Vergados (2011). 
tions and perspectives. The almost religious quality is counterbalanced by an occasionally rather non-cultic atmosphere where narratives about all too human deities create amusement and ironic detachment. Nonetheless, Hermes or Aphrodite in HHymns 4 and 5, for example, become present and gain epiphanic concreteness just in these traits.

Moreover, in some Hymns the gods, especially Hermes (HHymn 4) and Dionysus (HHymn 7), manifest themselves through signs, features, or $\mu \alpha \tau \alpha^{42}$ For the disclosure of their true nature, they give signs that require correct decoding and interpretation. Inside the narrated story, figures fail to recognize them, while the outside listener (or reader) clearly understands these markers. When Dionysus strikes back, assuming a terrible ( $\delta \varepsilon$ ivós) nature through metamorphosis into a lion and through the scenic production of a wild bear, he brings forth signs ( $\sigma$ '

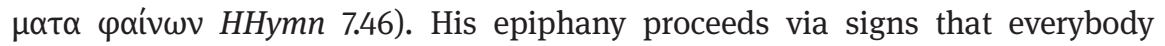
should realize. But signs bear a certain ambivalence. Like oracular words they are not clear-cut, but hard to recognize by nature. They can only allude to and hint at the higher truth, nodding to enigmatic allegoresis and indirect semiosis. ${ }^{43}$ In the "traditional referentiality", $\sigma \eta ́ \mu \alpha \tau \alpha$ can metonymically stay for well known traditional story patterns. ${ }^{44}$ The product of recalling, the $\mu v \tilde{\eta} \mu \alpha$, is also a $\sigma \tilde{\eta} \mu \alpha$, a symbol that has to do with a mental awakening and activation. Something is brought to consciousness, vóos, by the act of becoming aware of or noticing

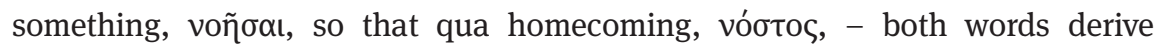
from the common root *nes- -, it can "return to light and life". As a reminder, the $\sigma \tilde{\eta} \mu \alpha$ is encoded according to the model to be decoded later on. ${ }^{45}$

The example of Parmenides describing the nature of "being" through ớ $\mu \alpha-$ $\tau \alpha$ provides an ideal foil to the revealing process through signs in the Hymns. The

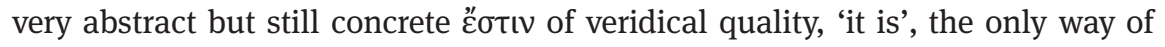
thinking, or as the deduced being, the ćóv, is a pure concept of metaphysical quality. It can only be grasped in a mental process, conceived as a very stable, everlasting, unchanging abstract entity. 'To it many oń $\mu \alpha \tau \alpha$, road-markers, are

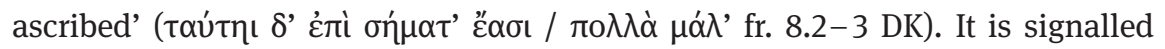
by reference to primarily negative attributes, expressed with the alpha-privative and substantiated by logic proofs. It is 'uncreated and undestroyable, complete,

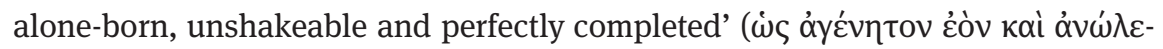

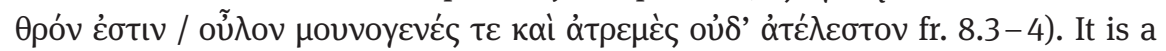
vón $\mu \alpha$ (fr. 8.34) about the essence of being, told by a goddess, and itself of meta-

42 See Vergados (2013) 15-22. On ớ $\mu \alpha \tau \alpha$ in general, see Nagy (1990b) 202-20.

43 See Vergados (2013) 15-22, esp. 20-2.

44 See Foley (1999) 115-67 and Bierl (2015) 193.

45 See Frame (1978) 81-115 and 134-52; Nagy (1990b) 218-19, (2013a) 275-8. 


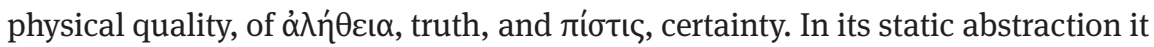
can be concretely conceived, compared to a round ball and neatly bound in the chains of cosmic necessity.

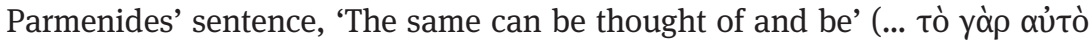

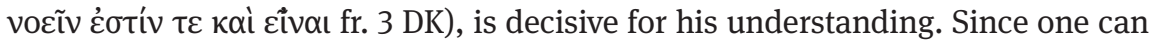
mentally behold and become aware of it, one can speak about it in rhapsodic form. The metaphysical essence thus becomes evident through pure logic and

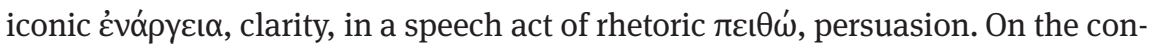
trary, in the Homeric Hymns hexametric poetry does not attempt to prove the static and abstract essence of being as eternal truth, but to unfold the dynamic and living essence of anthropomorphic gods through narration. The narrative part is not an abstract, but very vivid and amusing discourse about gods in action. The stories focus on Olympian gods in their making, on their essentials and prerequisites in action. The epic narratives reveal the gods' formative actions, deeds, honours or signs, when they materialize for the first time. In other words, the narrative process sets epithets in action. The features are remembered, dynamically exposed as they emerge. In this way the Homeric Hymns amount to an epiphanic disclosure in epic telling. By going back to the very origin and through a dynamic lens the poetic "I" tells about vivid and non-abstract divine personalities immersed in interaction with other figures. In short, the Hymns do not map static and metaphysical entities in close-up views, but narrate delightful stories about the essence of real gods in flesh and blood as they come into being. The Hymns remember them and bring them back to life in a mental and performative act through narration.

\section{Epiphany and mystery in the Hymn to Dionysus (HHymn 7)}

It is well known that Dionysus bridges dichotomies in a paradoxical manner. ${ }^{46}$ He oscillates between all possible polar oppositions, such as man-woman, man-ephebe, god-man-animal, inside-outside, life-death, Greek-Barbarian, quietness-motion, civilization-nature, cosmos-chaos, idyll-violence, happiness-suffering, order-destruction. Euripides summarizes this tension, calling

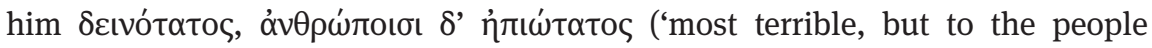
most gentle and kind'Bacchae 861). In his presence both sides of polar axes, un-

46 The entire paragraph is based on Bierl (2013a) 366-7; on Dionysus as the god of polar oppositions, see Otto (1933); Henrichs (1982) esp. 158; Bierl (1991) 14-20. 
derstood as energetic forces in dynamic reciprocation, tend to fuse and blur. Moreover, Dionysus is a god on the move and in constant change. He abounds in vital energy, making everything grow and sprout. His hallmarks are: wine, wild nature, vegetation and animality; madness and ecstasy; underworld and death; mystery cult and afterlife; sex and love; dance, music and performance; mask and costume; fiction, imagination, vision and miracle. Most of all, he always desires to become present. Thus, we see him arriving from outside or even from the realm of the dead, and he wishes to appear, manifesting himself

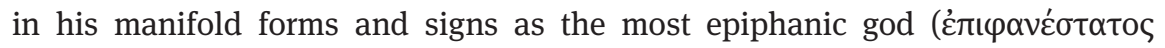

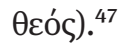

At the beginning of HHymn 7, the performer turns his thoughts to Dionysus

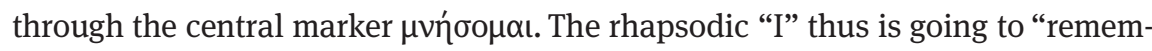
ber" how the epiphanic god par excellence produced an epiphany on the promontory close by the sea. ${ }^{48}$ In short, the epic singer will make Dionysus present in all his essential qualities and characteristics by telling how the god showed himself in a sudden apparition. Most of all, it is somehow an "epiphany in an epiphany", since Homeric Hymns in principle function on the basis of the model of epiphany. Furthermore, I argue that the ritual concepts of epiphany and mystery function as the decisive motors of the Hymn to Dionysus and configure its correct understanding. ${ }^{49}$ On the one hand, we can identify the mythic model of the arriving god who seeks recognition but meets resistance, captivation and violence. Through miracles the god, freeing himself, warns his opponent by revealing himself, until he finally punishes sceptical, irreligious people and rewards his followers. On the other hand, myth is complemented by ritual, particularly by the practice of the Dionysian mystery cult where the initiates inside the religious circle are opposed to the uninitiated people outside. It is striking that Euripides' Bacchae is based on the identical mythic-ritual scenario. ${ }^{50}$ While the longer

47 See the inscriptions of Antiochia CIG III 3979 und CIG 1948; on Dionysus' particular presence and tendency to show himself in an epiphany, see Otto (1933) esp. 70-80; Henrichs (2011). 48 Despite some recent interest, HHymn 7 has still attracted relatively little critical attention. See now Nobili (2009); Jaillard (2011); Herrero de Jáuregui (2013) on all three HHymns to Dionysus (1, 7, and 26).

49 On epiphany in HHymn 7, see Jaillard (2011); Herrero de Jáuregui (2013, 240 -1) mentions the aspects of mystery and mystic epiphany for HHymn 7 only en passant; Nagy (2013a, 659-64, esp. 664) associates the Hymn's hidden emphasis on salvation with the hero cult.

50 Seaford (1981), (1996) esp. 39-44; with the review by Bierl (1999); on the Bacchae as epiphany, see also Wildberg (2002) 149; Bierl (2004) 45; Bierl (2013b) 214-21. On HHymn 7 and the Dionysian concept of resistance that constitutes also the Bacchae, see Herrero de Jáuregui (2013) 244-6. 
Hymns tend to motivate everything in detail, in this Hymn of middle length everything seems to be sketchy, unmotivated, fuzzy and indeterminate. But, as Dominique Jaillard has well shown, this is not a flaw, a sign of lack of care in composition, but it reflects the poetic principle of presenting an adequate picture of this god in "iconic force". ${ }^{51}$

After the entrance formula in which the singer wants to fix his mind on Dionysus by "remembering" (1) how the god once suddenly appeared ( $\dot{\varsigma} \varsigma \dot{\varepsilon} \varphi \alpha ́ v \eta 2$ ) by the shore, the narration evolves directly from this scene. In a pointillist procedure, the singer-narrator sketches the scene: the god appears on the cliff, between sea and land, in the shape of a very young, almost feminine and goodlooking man at the very beginning of puberty. As in the Bacchae, he thus comes in human disguise. His dark locks are waving in the wind, a purple cloak over his strong shoulders (1-6). A beautiful, anthropomorphic figure his outfit promises money and wealth, at least for pirates passing by; all of a sudden, they show up, again unmotivated, sailing over 'the wine-coloured sea' (7), that is already associated with the god through this attribute. Economic greed for ő $\lambda \beta$ os, wealth and money, is their driving force. By kidnapping rich and beautiful men and selling them into slavery they make their living. Being all too human, they fail to recognize the god. The entire story is based on different degrees of recognition and misrecognition of the god and his prerogatives that thus appear in a blurred perspective. Inside and outside overlap in similar signs. But for the initiated people inside, recognizing and following the god in the process of his epiphany, Dionysus promises higher values, blessedness, happiness and true pleasure in the beyond, whereas the outsiders simply strive for momentary happiness in this life.

The narration plays with boundaries and frames the nucleus by ring-compo-

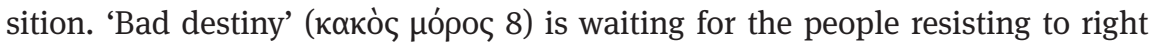

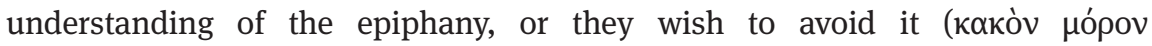

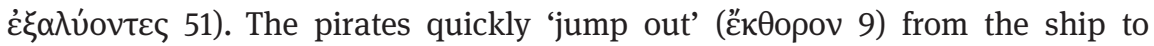

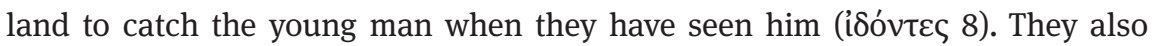
jump out ( $\pi \dot{n} \delta \eta \sigma \alpha v$ 52) from the deck into the sea, seeing (52) the terrible punishment of their leader. After the ephebe's seizure the pirates are 'happy in

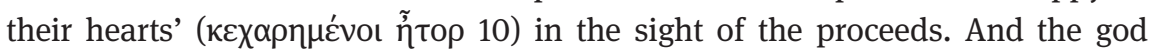
calls the steersman, the only person on the ship who recognizes him, $\kappa \varepsilon \chi \alpha \rho t-$ $\sigma \mu \varepsilon \dot{v \varepsilon} \theta v \mu \tilde{\omega}$ (55), 'having achieved beauty and pleasure for the god's heart'. Im-

51 Jaillard (2011) 150 and 144-50 (also in relation to the famous Exekias Cup). In the past scholars criticized the flamboyant style, the lack of coherence and poetic talent; see Gemoll (1886) 317; Humbert (1936) 169; Allen, Halliday and Sikes (1936) 379. 
mediacy and suddenness are the hallmarks of an epiphany. ${ }^{52}$ Therefore the sketchy narration is marked by signals and markers of urgency and speed. The hymn unfolds in a poetics of suddenness. The narrative steps proceed repeatedly 'all of a sudden' or 'quickly'. 53

The hymn permanently oscillates between recognition and misrecognition. On the basis of the stranger's look the pirates surmise - the irony of the hymn - that he might be a son of kings stemming from a divine line (11). Instinctively they forebode the revelation of the god's divine origin, but consciously acknowledge his looks only as an economic indicator. Their attempt to bind him fails, his first miracle. The bonds of willow fall automatically off his hands and feet $(12-14) . .^{54}$ The god does not take any steps of resistance, but nature acts for him. He sits in silence, 'smiling' ( $\left.\mu \varepsilon \_\delta \alpha^{\alpha} \omega v\right)$, and remains a detached observer (14), just like Dionysus in Euripides' Bacchae. ${ }^{55}$ Seizing the god mirrors and inverts the fact that in his cult, his followers are captivated by him. His frontal gaze with 'dark eyes' (15) means erotic attraction and danger. The steersman is the only one who becomes aware of the divine presence, mediating between the outside and inside. He steers the ship and its crew, sailing in the territory of Dionysus, i.e. the 'wine-faced sea' (7), ${ }^{56}$ on a journey towards him. By means of his mental "communication" with the god the steersman warns his comrades. He realizes that the beautiful ephebe is a god, but cannot say which one (17). Since the bonds could not hold him, not even the ship can do so (18). The present and super-human figure in the here and now could be Zeus, Apollo or Poseidon (19-20) - all three are mighty and terrible gods. The steersman thus sees through the disguise, albeit obliquely. Despite his human

52 See Bohrer (2015) 11-37, esp. 15.

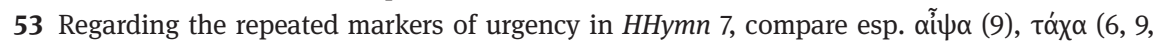

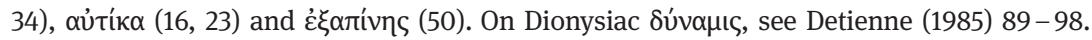

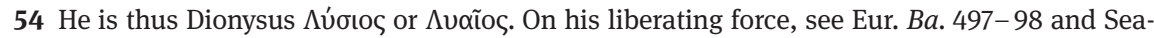
ford (1996) 190 ad loc. On bonds that fall off automatically, see Eur. Ba. 444-8. See also Merkelbach (1988) 103-4. On Dionysus and wonder, see Eur. Ba. 248, 449, 667, 693, 716. See also Merkelbach (1988) 109-11. On $\lambda$ úyos, willow or agnus castus, as an anti-aphrodisiac, see Versnel (1993) 247. To free from the bonds, on the contrary, thus means licence for sexual union. Pharmacological studies indicate that the consumption of a higher dose leads to a higher sexual activity. Therefore $\lambda$ úyo is as ambivalent as Dionysus. The pirates wish to control his erotic radiance, focusing on the economic value of the captivated youth. Yet, ironically, they bring him in touch with the plant so that his sexual appeal and beauty will even be higher.

55 Compare Eur. Ba. 439 (laughter; see Seaford 1996, 186 ad loc.; compare Ba. 1021), 621-2 (detached observer). On Dionysus' quiet reaction in Bacchae, see ňouxoৎ $(622,636)$.

56 On the epithet olv $\omega \psi$, see Jaillard (2011) 143 n. 28. At Eur. Ba. 438 the epithet is applied to Dionysus' cheeks. 
shape, the young man is not like mortal humans, but rather resembles the gods $(20-1)$. Therefore the steersman pleads with his fellows to release him, leaving him on land. They should not mistreat him. On the boat he might stir up terrible storms, like the god of the sea (22-4). As steersman, he is still mainly concerned with the men's safety at sea. Soon this will shift into the $\sigma \omega \tau \eta \rho i ́ \alpha$ of the initiates.

The leader of the pirates reviles him with hateful words (25), turning the steersman's reproach of being possessed by a supernatural, demonic power

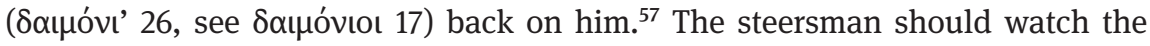
wind and do his job to steer the sailing boat with hissed sails (26-7). The beau-

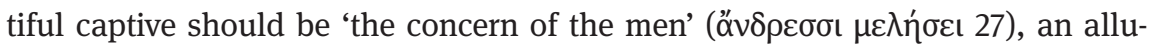
sion to the famous expression in the Homeric epic (Il. 6.492). ${ }^{58}$ But the words might allude to homosexual penetration of the female-looking ephebe as well. ${ }^{59}$ In full irony, the captain predicts that this mysterious man will lead them to foreign and utopic lands far away; after Egypt and Cyprus even to the Hyperboreans and beyond (28-9). This would be a journey to death, soon to extend beyond the range of mortals. Apollo, Dionysus' complementary brother, abides in the far north, in the fabulous land of the Hyperboreans, associated with myths and cults in Delos and Delphi. The leader, full of greed and hope, anticipates that on this journey the stranger will show them his dear friends and brothers, his possessions in the beyond, since a god, $\delta \alpha i \mu \omega \nu$, caused them to meet this young man $(30-1) .{ }^{60}$ Ironically, and according to his everyday diction, the leader associates him with the superhuman. The sailors have indeed encountered a god, who will function sometimes as friend and sometimes as adversary. Thus the god will show who is close and dear to him, according to the logic of the in-group of the initiated. Moreover, he will become manifest through his holy attributes.

Without any insight, the leader hoists the sails, and the wind starts blowing (32-3). The ship is sailing full speed over the stormy sea, the ropes are tight (33-4). At this point prediction becomes reality. Then, right away, the second stage of Dionysus' epiphany begins. All of a sudden, $\theta \alpha u ́ \mu \alpha \tau \alpha$ है $\rho \gamma \alpha$, 'things,

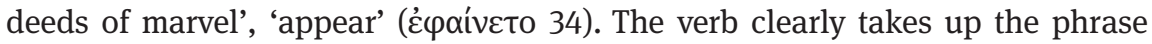

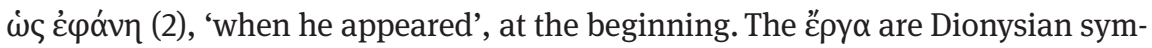

57 On Dionysus as $\delta \alpha i ́ \mu \omega v$, see Eur. Ba. 272.

58 See Prauscello (2007), who thinks that the expression implies that the steersman is somehow effeminate, like the young man. Herrero de Jáuregui (2013) 247 n. 34 suggests that it 'could be understood also as a threatening mockery of the scarce masculinity of Dionysos himself, from the viewpoint of the pirate, similarly to Lycurgus or Pentheus'.

59 On sex in mysteries, see Burkert (1987) 104-6.

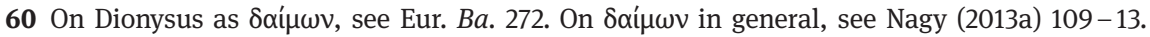


bols, signs or attributes. In a sort of Dionysian semiotics these attributes become alive, direct agents standing for their divine origin: sweet wine of fine smell splashed in the boat (36-7). The reaction to this unexpected presence of the main features of the god is amazement (37). Then, at once, at the top of the sail, on both sides, a vine spreads out, with many grape clusters hanging thereupon. Around the mast black ivy is winding around, teeming with blossoms, the fruit full of beauty and pleasure like the god himself (and his attendant symbols). The benches hold cultic garlands $(38-41) .{ }^{61}$ The Dionysian, affecting all the senses, takes possession of the ship. It is a series of positive signals, making the ship into a cup, a vessel of his inebriating drink and plants. The positive warning, focusing on epiphanic signs of xápı, , beauty and pleasure, is successful, as far as the crew is concerned. Realizing the miracles and responding with amazement and fear, the pirates are ready for a reversal. They thus start giving loud orders to the steersman to return to the land (42-4). It remains an open question whether they want to flee or to set free the kidnapped young man. Be that as it may, on his element of the sea, the god becomes present through signs that belong to his power on land. In various festivals he is envisaged as arriving from the sea, entering into the cities in triumphant processions. ${ }^{62}$ The steersman cannot react since, at this point, Dionysus starts with the third phase of his epiphany, now of a wild, terrible nature. With these manifestations the god intends to punish his opponents and trigger new metamorphic changes (44-53). Dionysus typically turns into a terrible lion to scare everybody with his roaring voice (44-5). In the Bacchae Pentheus is also frightened by imaginary monsters and wild beasts. ${ }^{63}$ In addition, in the middle of the ship he made a bear with a shaggy neck (45-6). Like a director, he makes this additional beast, another miracle, appear on the imaginary stage, put forward through narration. After all, the singer summarizes the entire epiphanic scene with the ex-

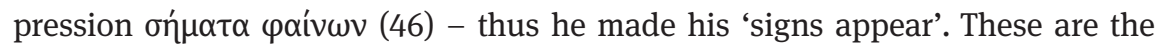
features of the god enacted in a mental and narrative act. Since a god cannot have a direct, full-fledged epiphany, he must recur to signs. The epic singer embeds them into a narrative plot full of beauty and pleasure. They have to be read, decoded and understood by the figures inside and by the recipient. As Dionysus oscillates between positive and negative signs, it makes sense that he does not

61 On ivy and vine as cultic attributes, see Blech (1982) 183-210. On garlands, see Merkelbach (1988) 99.

62 See Burkert (1983) $200-1$.

63 Agaue believes that she hunted a lion $(\mathrm{Ba} .1196,1215)$ or a beast $(1204,1237)$ instead of Pentheus; Dionysus is seen as a beast $(920)$, bull $(618,920,1018)$ or snake/dragon $(1019)$. On frightening terror in initiation, see Merkelbach (1988) 104. 
refrain from making use of his violent side either. As stage director he makes the bear in raging voracity rear up and the lion, his new disguise, on top of the deck, look horrific to them (47-8). The men of the crew, in their terror, thrust themselves into the stern, seeking help from the steersman, who has a heart that is

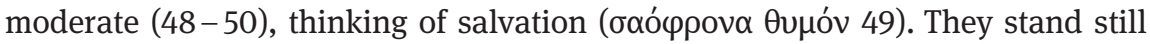
in terror and marvel (50). But the lion, all of a sudden, leaps up and seizes

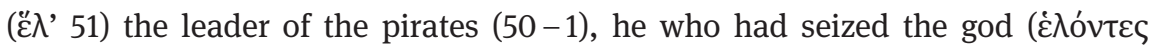
9) at the beginning. The opponent will be devoured, but the men under the rule of this leader, in their astonishment and terror, trying to flee from their bad destiny, leap all together out into the divine sea. They turn into dolphins (51-3), the Dionysian and most intelligent "fish" and the animal that brings salvation from the sea. ${ }^{64}$

The jump from the deck means death. But the transformation into dolphins means new life. It emblematizes the entire paradox of Dionysian ritual and its mythic narrative complex, bound to the logic of the mystery. The jump into the sea or into a liquid is a typical motif of mysteries. I only recall the famous

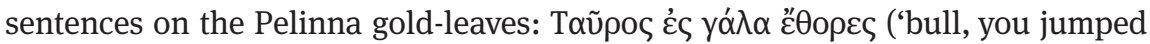

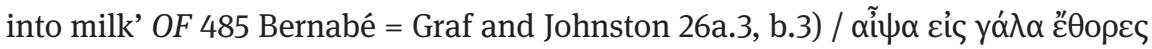
('quickly, you jumped into milk' OF 486 Bernabé = Graf and Johnston 26a.4) - fol-

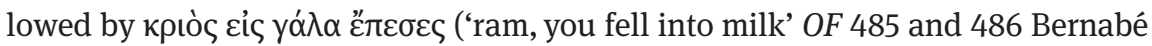
$=$ Graf and Johnston 26a.5, b.4). ${ }^{65}$ The initiate experiences death only to be reborn again. He dives into the unknown, the wine-coloured sea associated with

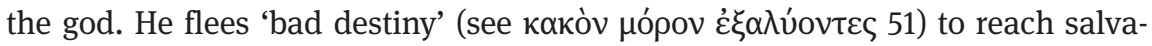
tion, ${ }^{66}$ and thus a good and blessed destiny. We can compare the typically mystic

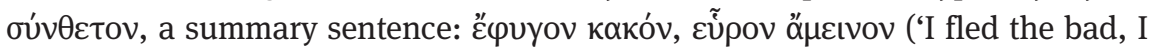
found the better' Dem. 18.259). Furthermore, Eric Csapo and others have pointed out that the myth represents the aetiology of the Dionysian chorus, dancing and leaping around the chorus leader. ${ }^{67}$ The ideal chorus leader is the $\kappa u \beta \varepsilon \rho v \eta \dot{\tau} \zeta$, the steersman, the one who steers both the ship and its men through the dangerous sea, likewise the circular chorus. According to Parmenides (fr. 12.3 DK), a fe-

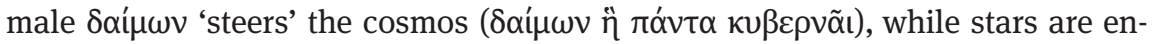
visaged as choruses as well. ${ }^{68}$ Heraclitus (fr. $41 \mathrm{DK}$ ) believes that a certain insight

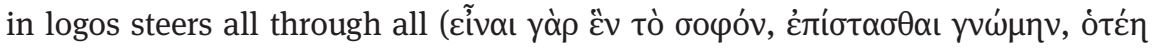

64 See Burkert (1983) 196-212.

65 For aĩ $\psi \alpha$ and $\theta$ opعiv, see also HHymn 7.9.

66 In the Orphic Hymn 74.6 Leucothea is adressed as bringing relief from the 'miserable destiny'

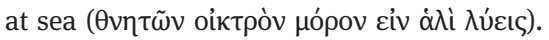

67 Csapo (2003) esp. 90-4. See also Lonsdale (1993) 93-9.

68 See Csapo (2008). 


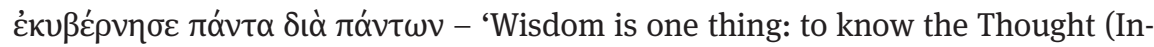
telligence) by which things are steered through all (ways)', translation M. Marcovich fr. 85). From archaic and early classical times we possess presentations of dolphin dancers and comasts in cyclic formations on vases. ${ }^{69}$ Salvation and blessedness come out of the sea. They also derive from the singing and dancing chorus and from the choruses of the Nereids accompanying the dolphins. This

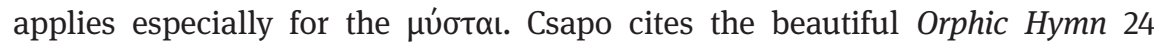
(Quandt) to the Nereids. ${ }^{70}$ Their chorus is accompanied by the chorus of 'wet-domiciled, leapers, winding about the waves, sea-wandering dolphins sea-surge-re-

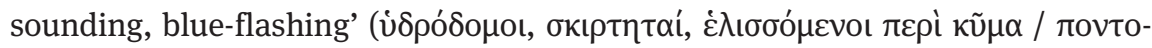

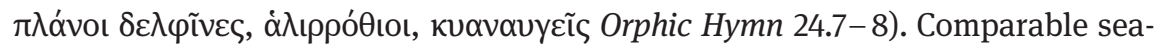
leaps are known from Arion and Melicertes, as both are associated with transformation, transport to new territories, and with Dionysian mysteries. ${ }^{71}$ Next to Dionysus, both mythic figures were linked to Poseidon and Apollo. This fact might be the reason why the steersman believes that these gods play a role (19-20). According to the famous story told in the Iliad (6.131-7), Dionysus, when threatened by Lycurgus, the typical $\theta \varepsilon$ coúxos, with violence, takes refuge in the sea, 'diving ( $\delta \dot{v} \sigma \varepsilon \theta$ ') into the wave of the sea', Il. 6.136), and the Nereid Thetis receives

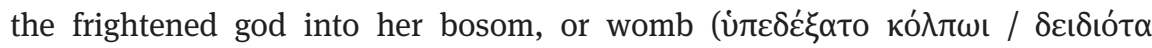
Il. 6.136-7). In the Homeric Hymn 7 the roles are changed: it is now Dionysus who frightens the pirates so that they jump into the sea.

A further evidence for a link to mysteries is the fact that Dionysus takes pity on the steersman, ${ }^{72}$ who as a moderate and wise person has always seen that there is a god behind the stranger. The anonymous steersman expresses the idea of the meaning in a generalized program of action. ${ }^{73} \mathrm{He}$ is the one who steers, and he both belongs to the group of pirates and does not. Moreover, he stands in strong opposition to their leader (ápxó $)$ ) who does not recognize

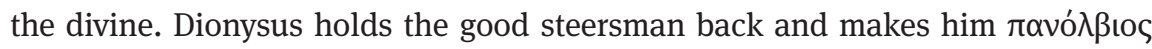
(54), a typical quality of initiates. The adjective ö $\lambda \beta$ เоৎ, likewise $\mu \alpha \dot{\alpha} \alpha \rho \rho$, has a double meaning, according to its occurrence in the unmarked or marked sense respectively. For the uninitiated it simply means 'fortunate' and 'rich', in a sec-

69 See Csapo (2003) esp. $78-90$.

70 Csapo (2003) 93.

71 See Csapo (2003) 86 with n. 55, regarding Palaemon. See also the Orphic Hymn 75.

72 Pity for the select person, encountering the mystic fears and sufferings with his group - is perhaps another characteristic of mysteries; see Merkelbach (1988) 148, 168, 186, regarding Longus' Daphnis and Chloe.

73 On the lack of names in the context of a general detachment, esp. in local regards, to express the idea Panhellenism, see Herrero de Jáuregui (2013) 242 with n. 21. 
ular and material sense. But for initiates, when they have reached deeper knowledge, it bears the meaning of 'happy' or 'blessed'. ${ }^{74}$ We can compare the passage to Sappho's recently found Brothers Song, where we encounter a similar discourse about material profit through sea-traffic, that assumes also a mystic meaning. ${ }^{75}$ On this basis we can speculate about the narrative setting of pirates and seafaring. ${ }^{76}$ It thus becomes evident that the related motifs do not reflect only a historical development, but allude to a deeper mystic subtext. Dionysus makes the steersman 'completely blessed' (54), since he excels everyone else in the group of happy dancers who are leading a blissful existence as Dionysian animals after their transformation. As mammal fish, the dolphins ( $\delta \varepsilon \lambda \varphi \tilde{v} v \varepsilon \varsigma)$ are named after the female uterus, $\delta \varepsilon \lambda \varphi u ́ s . ~ D i o n y s u s '$ birth from the womb of his mother Semele, impregnated in love by Zeus, is the decisive feature of the god, even in his self-presentation $(56-7$; see 1,58$)$. The leap from the womb in an early birth, triggered by Zeus' lightning, is the very first, the original appearance of the epiphanic god. The initiate, so to speak, returns into the sea, the maternal womb. Similar to Dionysus sinking into the bosom or womb of Thetis under the sea (Il. 6.136-7), the initiate mentioned in a gold-leaf in Thurii says 'I have sunk beneath the breast/lap of the Lady, the Chthonian Queen' ( $\Delta \varepsilon \sigma \sigma \pi$ tí $^{-}$

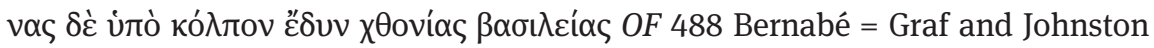
5.7) ${ }^{77}$

The prominence of a mystic subtext becomes again clear by the fact that the much more detailed narration in Ovid's Metamorphoses (3.582-691) makes the context of mysteries explicit. The episode is put in a frame that mentions twice the new Bacchic mysteries (morisque novi sacra 3.581 and Baccheaque sacra Ov. Met. 3.691). In Ovid's first-person narration in front of Pentheus, the steersman is called Acoetes, telling the story about the epiphany of the most present god - nec enim praesentior illo / est deus (3.658-9). In the god's body

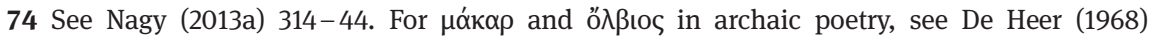
esp. 28-38, 51-55. For the $\mu \alpha \kappa \alpha \rho ı \mu$ '́, the praise of the blessed condition for those witnessing the mysteries, see HHymn 2.480-2; Soph. fr. 837 Radt; Eur. Ba. 73-4; in several instances we

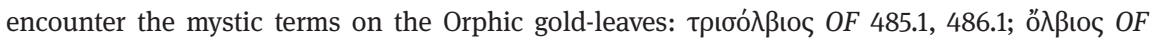

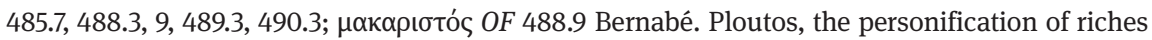
and wealth, is also involved with mysteries, esp. in the Eleusinian context: see Burkert (1987) 20.

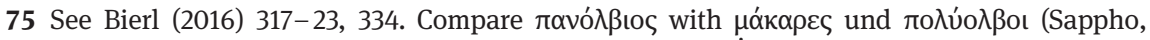
Brothers Song 19-20) On Charaxus as programmatic name, containing $\chi \alpha \rho \alpha ́$, joy, see Bierl

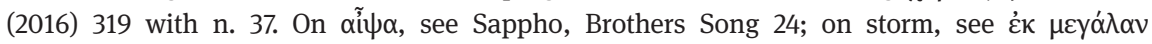
ơñ 76 Regarding Sappho's Brothers Song, see Bierl (2016) esp. 318.

77 The expression might allude to sexual practices; on Sabazius/Dionysus as $\theta$ cò $\delta$ เò кó $\lambda \pi$ rov and rites of symbolic sexual union with the god, see Burkert (1987) 106. 
of maiden beauty Acoetes recognized the divine (corpore numen in isto est 3.612). Moreover, the name Acoetes could allude to the sexual aspects of mysteries. As ókoítns he is the potential lover of the homosexually-marked god. It is well known that erotic practices, remainders of the first encounter with sexuality in puberty initiation, played a certain role in Dionysiac mysteries. ${ }^{78}$ Since he is the select and the only person left, his closeness to the god is imagined in a sexual union with him. In Ovid's version also, the choral dimension of the whirling dolphins is made explicit, 'as they play in the form of a chorus' in the water (inque chori ludunt speciem 3.685).

In the Homeric Hymn to Dionysus everything remains more hidden, in the dark, and enigmatic. The recipient must decipher and interpret the signs that

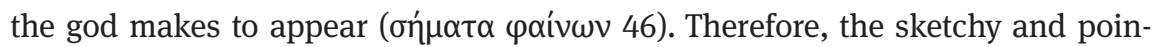
tillist poetics is not only a matter of a new technique based on the iconic, on images and the imaginary, ${ }^{79}$ but it exerts a direct function in the narration, associated with the decisive feature of the mystic quality that unfolds in epiphany. Dionysus feels pity for the outstanding and select person, who must endure the mystic fears and sufferings together with his group, and saves his life. The steersman of moderate character, possessing sound thought, experiences salvation and blessedness. Choral dance belongs to this elevated state of mysteries. The dolphins, the enthusiasts of music and dance, leap and wind around the ship in the Dionysian element of sea, associated with wine. The steersman, as representative and surrogate of Dionysus, stands in the middle, on the ship, steering their choral movement. But behind him, at a second remove, is Dionysus, the divine chorus leader. He addresses the still frightened steersman with

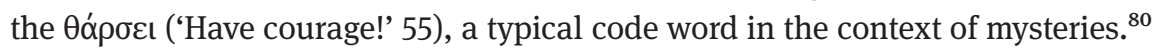

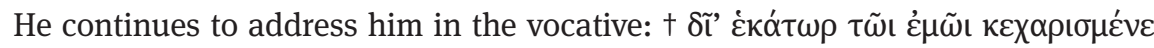
$\theta v \mu \tilde{\omega}$, 'radiant and divine man, affected by a power from afar, who has become beauty and pleasure for my heart' (55). He became divine, since a god reaches his heart, while the god is filled by the pleasure of the new initiate's attitude. The address stands in stark contrast to the beginning, when the pirates were

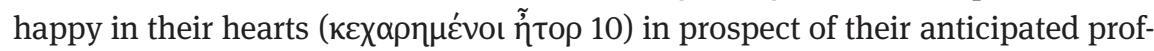

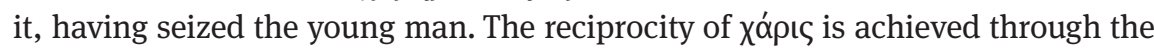

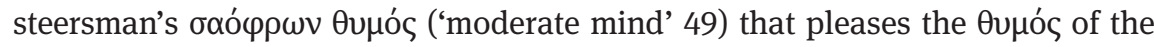

78 See Burkert (1987) 104-6.

79 See Jaillard (2011).

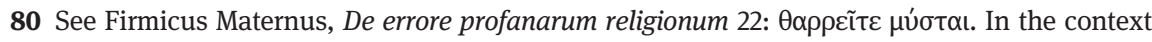

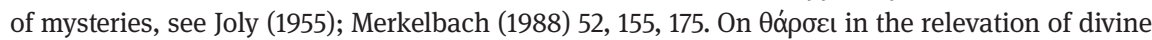
identity and epiphany, see Il. 24.460; HHymn 2.120, 268; HHymn 5.193 (in the ironical, playful way). 
god (55), but even more so in view of the beautiful chorus. Its leader is the steersman, but even he is driven by a transcendent force. It is Dionysus himself, the hidden and divine chorus leader at the very centre of his whirling chorus. The chorus reaches out to the ship, the entire sea, to the sky, to the cosmos. Everything has become a Dionysian $\sigma \tilde{\eta} \mu \alpha$ and thus a $\mu v \tilde{\eta} \mu \alpha$, singing, dancing and creating a synaesthesia of choral performance. Sound, sight, smell - all together envelope the god, the origin and destination, in total pleasure. Therefore, in the last step of his epiphany, he finally reveals himself with a solemn self-repre-

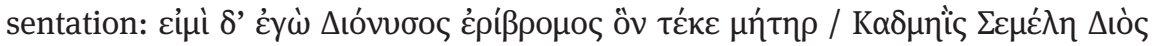
¿่v $\varphi$ ı whom as mother bore Semele, daughter of Cadmus, having mixed in love with Zeus' $56-7) .{ }^{81}$ In the very first verses of Euripides' Bacchae (1-3), itself built on the model of an epiphany, Dionysus, as god coming from afar, somehow re-

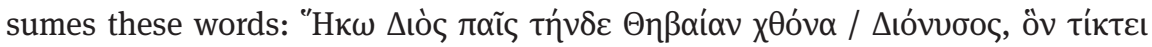

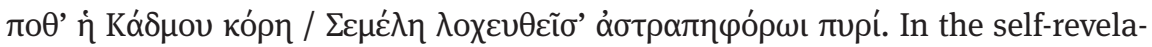
tion of the Homeric Hymn 7 Dionysus emphasizes his roaring sound, i.e. his acoustic dimension as choral god. ${ }^{82}$ By mentioning also Semele and Zeus, he further stresses his epiphanic quality, his birth in a sudden lightning. Dionysus speaks of the mingling in love, the main feature of the hymnic and cosmic dimension of the Orphic prehistory of the hymn. ${ }^{83}$ Inside the story, the god of choral dance, mystery and epiphany has finally revealed himself; that is what the performance re-enacted qua song. Thus he is pleased by the beauty of the chorus that has been narrated in its very making, and the chorus leader, whom he kept back and saved. At this point, after the final revelation, the singer shifts to his farewell formula of $\chi \alpha$ ĩ $\rho \varepsilon$ - 'farewell and find pleasure, son of the nice-looking Semele' (58). Since Dionysus took pleasure in the beauty of song inside the narrative, he should also take pleasure in the performance of the actual song outside the narrative. The performance brought the god to life in his essence, the divine force of song and mysteries. The beauty of the god, the son of Semele with beautiful eyes and responsible for wonderful music and song, radiates grace. In a chain of musical transmission, song is transferred from the divine choral leader Dionysus via the initiated steersman and his chorus of dolphins to the performer of the hymn. Therefore he prays to receive his share of grace also for future song production. In the logic of the xápıৎ-reciprocity the perform-

81 For such self-revelations in later texts, see Merkelbach (1988) 53. For the expression $\varepsilon v$

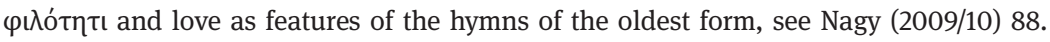

82 On the acoustic dimension, see Jaillard (2011) 149. On the sound aspect of the epiphanic parodos of the Bacchae, see Bierl (2013b).

83 See Nagy (2009/10) 88. 
er states his deep loyalty to the god of song and mysteries. He has offered pleasure to the god by telling how the god took pleasure in his chorus, the first initiates of his mysteries, narrated in the very process of their coming into being. The rhapsodic singer is well aware of the fact that this "mind act" of re-enacting the god accomplished the song about the god and made the god thus present. Since the god took pleasure in it, the performer hopes that the god's radiance and beauty will extend this effect to his next epic song and all future performance. As musical follower, he knows very well: 'It is impossible for me, who

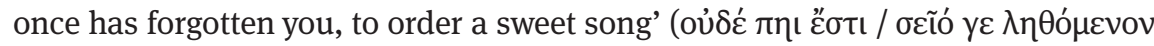

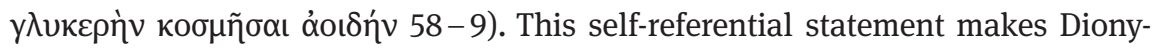
sus, the principle of choral song, hymn and mysteries, the very source of the performance, at least in this particular domain. He never asked a Muse or Dionysus to receive inspiration at the beginning of the song. But by remembering him, making him present in a mind and speech act, he is mentally connected with him so that Dionysian grace and beauty automatically enters and vivifies his song. ${ }^{84}$

In the fragmentary Hymn 1, as well to Dionysus, obviously focusing on his birth, we have a similar self-referential connection of the performance with the god of music and song. Indeed, in the very end where the hymn shifts to the performative frame and new epic songs, the hymn speaks about the rhapsodic singers in the plural, including the entire guild and all future singers of re-perform-

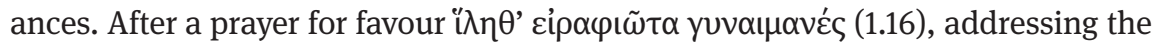
god with very marked epithets, the 'insewn' (or 'the one of the shape of the ram') and 'the one maddening women', the performer emphasizes that he is well aware that the singers must mentally connect with their source Dionysus. 'We singers sing of you in the beginning and in the end, and it is impossible to have one's mind disconnect from you as anyone recalls to mind the holy song' (oi

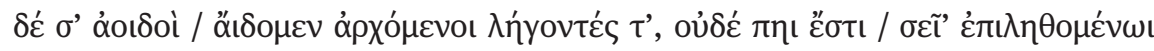

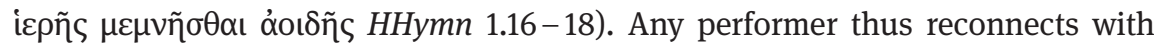
the god while making him present. The mental connection must be accomplished in the introductory part, where the performer usually speaks about his performative intention to bring the god, in this case the god responsible for song, music and dance, to mind, making him present through a third-person narration. After the narration, the mental contact must be installed again, as it happens here. The god has been pleased by the song, he should take beauty and pleasure in it, the god sewn into the thigh of Zeus but also "sewn" into the texture of the hymn; üHvos means 'woven texture' as song and the rhapsodes are the singers

84 See also Nagy (2013a) 659-64, esp. 663-4. 
who "sew" songs together (from ṕó $\pi \tau \omega$, to 'sew, stitch'). ${ }^{85}$ In the composition in performance or in its written manifestation, the singer puts his song together, picking the decisive features to ensure the god's presence. As the god born by Semele in the most epiphanic birth triggered by lightning and thunder, Dionysus must be sewn into his father's thigh serving as second womb until he can be born as a mature baby. Also, his songs are palimpsests, overlays and mixtures of textual levels, hybrid compositions taken from different traditions and sewn

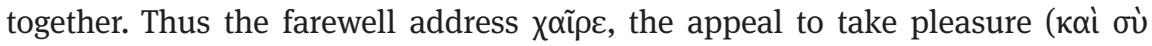

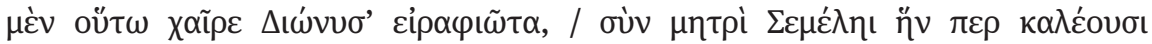

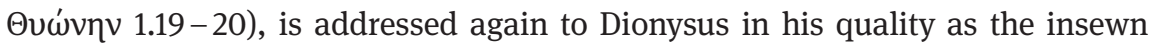
god and to his real mother, who bears the name Thyone, etymologically associated with "smoke" and "mind", and thus 'energy' in poetic and epiphanic per-

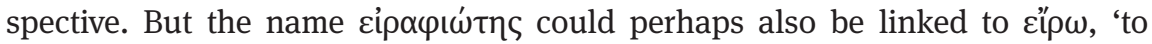
put in series', 'knit', thus another hint at the level of composition and performance.

\section{Epiphany and choral festivity in the Hymn to Apollo}

In the longer Hymns the main gods, to whose honour the hymns are sung, are often in interaction with other Olympian gods. This was not the case in the long Hymn to Dionysus, where he acts as a singular and independent figure. But, to some degree, we can put the famous HHymn 3 to Apollo next to HHymn 7. Besides common themes, such as a focus on song, epiphany, arrival, and dolphins, it is well known that both gods exert a complementary function and are in close contact with each other in the complex polytheistic system.

At this point, we must mainly leave aside the long discussion about the Hymn's unity. Much ink has been spilled over an original divide between the Delian and the Delphic part or an original cohesion. Today most critics subscribe to a unitarian view. In this regard, Jenny Strauss Clay's opinion that highlights the Panhellenic ideology and the mythic-narrative coherence is the most influential. As for the other longer Hymns, Clay argues that this Hymn, fulfilling a specific Panhellenic agenda, narrates the installation of fundamental deeds and honours of Apollo as well, after the establishment of Zeus' order. ${ }^{86}$ David Ruhnken was the first scholar who pleaded for the Hymn's separation into two parts, recogniz-

85 See Nagy (1996) 64.

86 Clay (1989) 17-94; see also Stehle (1996) 177-96. 
ing that lines 165-78 correspond to the typical ending strain. ${ }^{87}$ Both parts constitute a coherent entity in themselves, but the Pythian part, despite a prologue, does not have the typical hymnic opening. In a separatist vein, Wilamowitz famously argued that the Pythian part was a later addition, imitating the earlier independent Delian part so that they were put together at a later stage. ${ }^{88}$ Another attractive theory has been developed by Richard Martin, who argues that the apparent division reflects a competition of two performers, the first part in the Homeric mode, the second in the Hesiodic mode. ${ }^{89}$ But be that as it may, if we focus on later re-performance we realize that both units were artfully put together over a longer period of revisions and adjustments so that our unified single Hymn, where it is hardly possible to recognize the stitching seam, perfectly works to demonstrate Apollo's essence. Following an evolutionary model, in which single units grow to a perfect unity over a diachronic chain of compositions in re-performances or orally based re-adjustments, we can just look on how the Hymn functions in a neounitarian way. ${ }^{90}$

The two parts correspond also in the microstructure. ${ }^{91}$ At the beginning and the end of each part we encounter passages that focus on epiphany and music in a double ring-composition. After all, we can speak of an aesthetics of framing, looping and mise en abyme effects. These features serve again to make the god present. Like his complementary brother Dionysus, Apollo is extremely ambivalent, but much less mysterious in blurring binary differences. As the 'God of Afar' (Wilamowitz), Apollo is strangely removed and yet very near. His effect as Loxias is of "oblique" quality in dual polarities. This trait becomes particularly prominent in his oracular speech, giving only signs to decipher (on $\mu \alpha$ íveıv, see Heraclitus fr. 93 DK). ${ }^{92}$ Sometimes he seems rather isolated, speechless and enigmatic, despite his responsibility for assemblies and political council. This means that, as the god of the bow and arrows, Apollo is brutal, violent and frightening, but at the same time, as the god of the lyre and chorality, he is idyllic, giving

87 Ruhnken (1749).

88 Wilamowitz-Moellendorff (1916) 440 -62; West (1975) pleads for the opposite: the Delian part would be a later composition, imitating the Pythian, put together by Cynaethus of Chios. Burkert (1979) argues that the occasion of the Hymn was the Delian-Pythian festival organized by Polycrates in 523/22 BC.

89 Martin (2000); for a history and reassessment, see Chappell (2011). For further literature on the HHymn 3, see Förstel (1979); Miller (1986); Martin (2000); Bergren (2008) 131-60; Peponi (2009); Nagy (2008/09) 196-206, (2009/10) 12-20, (2011), (2013b); Olson (2017).

90 See Nagy (2012) esp. 30. On the evolutionary model, see Bierl (2015) 186-91.

91 On a survey of "paired affiliations", see Martin (2000) 409.

92 Fr. 93 DK = 14 Marcovich (translation): 'The Lord whose is the oracle in Delphi neither speaks out nor conceals, but gives a sign ( $\sigma \eta \mu \alpha i ́ v \varepsilon l) '$. 


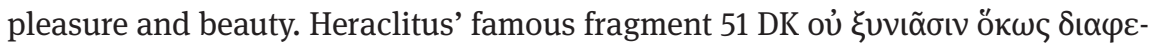

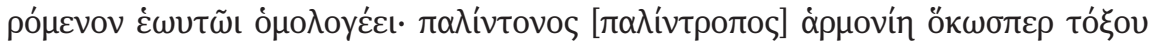
кaì $\lambda u ́ p \eta \varsigma$ ("men do not understand how what is being brought apart comes together with itself: there is a connexion/harmony caused by opposite tensions ( $v . l$. turning back), that of the bow and of the lyre') reflects the complex ambivalence of the god and the 'palintropic harmony' also reflects the situation of this hymn. ${ }^{93}$

Again at the very beginning, we have the voice of the rhapsodic "I" who

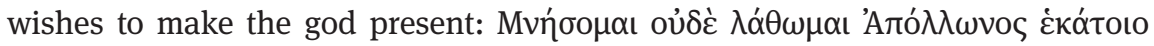
- 'I am going to bring to mind and never pass over Apollo, the far-shooter' (HHymn 3.1). The narration immediately shifts with a relative pronoun into a scene of arrival (2-12). The arriving god triggers terrible fear because of his bow. All tremble and spring up when he bends the bow (2-4). Only his mother can unstring it, after which she takes it off her son's shoulders, hangs it on a peg and make her son sit down (5-9). Leto is the main focus of the narration relating how this god came into existence on Delos, another typical scene of a revealing epiphany. But before shifting into the narration about Apollo's birth, the poetic

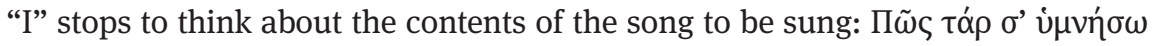

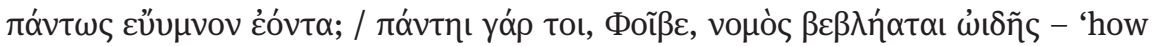
shall I sing of you who in all ways are a worthy of a good song? / For everywhere, Phoebus, the whole range of song is fallen to you' (19-20, translation after H. G. Evelyn-White). The whole world is resounding with song about him, the god of music. In reciprocal fashion, he is the subject of good song and therefore songs are sung everywhere about him. But the climax, in this respect, is the rocky and empty island of Delos. Yet it took some time to reach this rather unexpected status. All islands trembled and felt fear, when only thinking about granting his pregnant mother the license to give birth to him (47-8). Since many islands did not grant Leto, on her long trip through the Greek world (29-46), permission, Delos must be praised for her courage for having done so. But first, afraid of the hubristic evildoer Apollo (67) and his violent behaviour, Delos is eager to make an agreement with Leto. As a matter of fact, the rocky island fears that the terrible god could scorn her and make her fall into the sea. Since nobody would care - nobody lives there (78) - Delos demands a temple (80) so that many people can come on $\theta \varepsilon \omega p i$ í, holy missions, to celebrate annual festivals there (61-82). Leto swears the oath, after which a miraculous birth can take place (83-119). As soon as the baby Apollo has eaten of the

93 The translation is based on M. Marcovich (fr. 27). On the 'palintropic harmony', see also Bergren (2008) 154. On a brief survey of Apollo, see Burkert (1985) 143-9. 
divine food, all cords cannot hold him any more in his bed. Freeing himself, he at once raises a claim on the kí⿴囗⿱一一) (his lyre), the bow and prophecy (127-32):

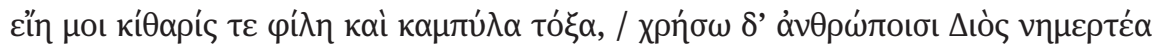

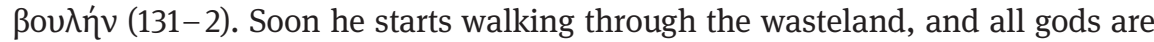
amazed (133-5). Wonder is the typical reaction to an epiphany: this is an apparition, not before men, but before his fellow gods, who are quite afraid of this apparently outstanding and exceptional god (2-4). In contrast to the other gods, Apollo is not seen in an anthropomorphic disguise.

Apollo's birth is pure wonder: his paraphernalia triggering astonishment are his bow and his lyre. Music will be the field where he produces marvels on Delos and elsewhere. As a god walking on the heights, always close to Mount Olympus, he looks down to his island where the oaths are quickly fulfilled (140-5). The Delian part ends with two most self-referential passages, where hymnic music is put en abyme in order to show the god in his essential nature (146-78). Looking down, he recognizes marvellous choruses. At this point the singer addresses

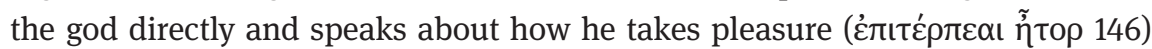
in the first Delian competition: 'there the long-robed Ionians gather in your honour with their children and chaste wives: with boxing and dancing and song' (147-9). Engaging Apollo to facilitate his presence, they please him ( $\mu \nu \eta \sigma \alpha ́ \alpha \varepsilon v o$ เ

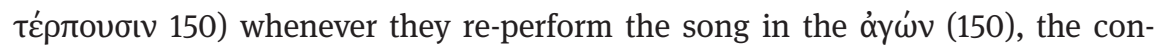
tests taking place at the occasion of the annually recurring festival. Especially through refined and beautiful choral hymns, the performers are mentally linked

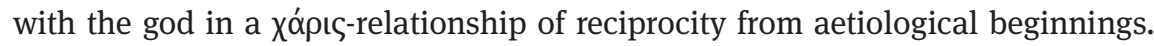
Whenever a stranger would join them and see their grace (151-5), he would say that these dancers are 'immortal and ageless' (151). This means that the performers, connecting with the god and with the original choruses, gain an almost divine status in the eyes of later generations. It is as if they received from Apollo, as they pleased him, all his divine beauty and grace. This potential visitor would

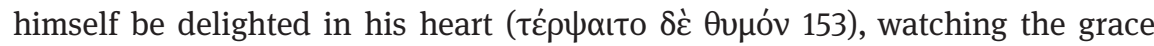

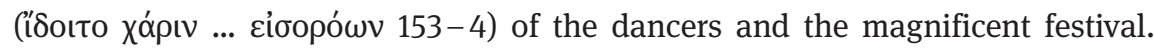
Moreover, he becomes the ideal emblem of any future audience, enchanted by the choral spectacle and later by the monodic-rhapsodic recitation of the Hymn in itself. In this unfolding chain of performances and re-performances in diachrony, Apollo and his Delian Maidens will have their eternal epiphany. Through hymnic song and via his attendants, the god will be present forever;

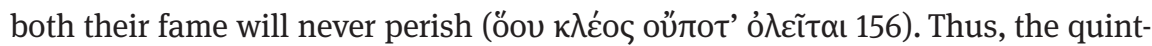

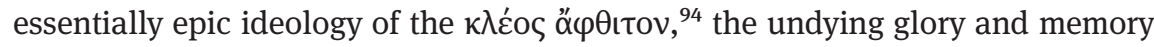

94 See Nagy (2013a) 26-31. 
of the heroic past, will be transferred to the very presence of the Olympian god and his medium. Moreover, all future re-performers of hymns praising Apollo, the source of their beauty, will have again a model, the Delian Maidens, a form of local Muses, the subject 'of great marvel' and 'never-ending fame' (156):

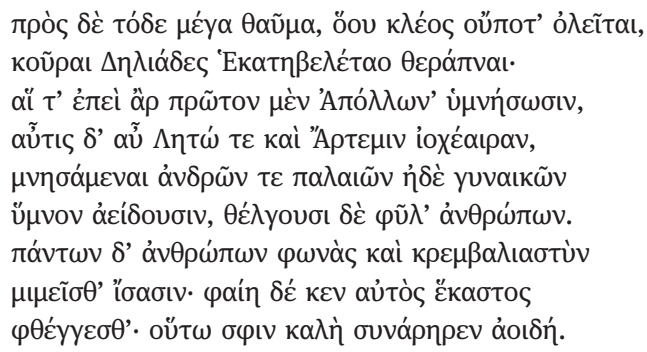

And on top of that, there is great thing of wonder, the fame of which will never perish, the Delian Maidens, attendants of the one who shoots from afar.

So when they sing their hymn in honour of Apollo first and foremost,

followed in turn by Leto and Artemis, shooter of arrows,

they keep in mind men of the past and women too,

as they sing the hymn, and they enchant all different kinds of humanity.

All humans' voices and rhythms

they know how to re-enact. And each single person would say that his own voice was their voice. That is how their beautiful song has each of its parts fitting in place.

HHymn. 3.158-64 (translation G. Nagy)

The Deliades are another personified emblem of local and Panhellenic memory, not only making present the god but also the first human performers of the past. As perfect singers they are experts of $\mu$ ín一бıc, re-enactment. Through voice they thus re-enact all possible performers who praised the god in the progressive chain of choral competitions. Everyone in this chain, even future rhapsodes performing at the annual Delian festival, would say that they shape their songs on the model of the ideal maiden singers and in full harmony with them. ${ }^{95}$

At this point, at the end of the Delian part, the farewell address goes to Apollo and Artemis (165), and finally to the Delian Maidens (166). They all should

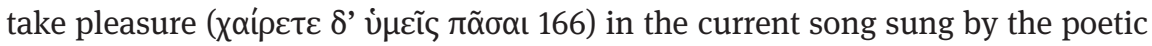
"I" as well. Now comes the surprise: they should keep him in mind even in the

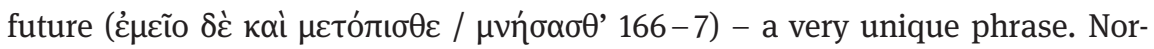

95 See Nagy (1990a) 42-5; on the mimesis of the Delian Maidens, see Nagy (2008/09) 198-206; Peponi (2009) esp. 62-8; Nagy (2013b) esp. 227-40; on the choral aesthetics of the entire passage, see Peponi (2009). On the festive poetics and aesthetics, see Bierl (2011) 125-38, esp. 136-7; on "kinesthetic empathy" and audience response, see now Olson (2017) 158-63. 
mally it should be the turn of the performer to remember the local Muses and, in the last instance, Apollo himself. But now the Delian Muses should remember him, the rhapsodic "I" - as if he were the god; when someone in later generations should come and ask ' $O$ Maidens, who is for you the most pleasurable of singers that travels here? In whom do you take the most pleasure?' (169-70),

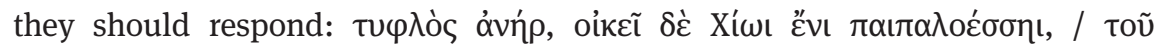

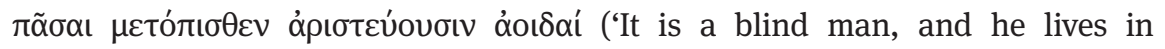
Chios, a rugged land, and all his songs will in the future prevail as the very best'. (171-3). At this point, by changing into the first person plural, he speaks in the name of the entire guild of the Homeridae. They, including himself, promise to carry the Delian Maidens' fame all over the world. The listeners of the per-

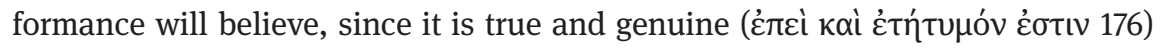
$(174-6)$.

This famous end of the Delian part thus highlights the original essence of the god by focusing on the medium in a self-referential manner. The epiphany evolves through the medium and the performance. In a looping effect the god manifests himself at the top of the cascade of hymnic singers. In a diachronic chain of hymns we pursue a long line of performances sung by his Delian attendants; via numerous choral re-performances as perfect re-enactments inspired by these Muses, we finally come to the monodic-rhapsodic hymn, our Hymn to Apollo. The text even throws a glance into the future. The god, the origin of song and music, and his Muses will always be praised in further re-performances. But next to the god and the Delian Maidens, now the performer/composer of this perfect Hymn comes into the play. With him the first chain of free and fluid performances comes to an end. He claims to have sung the best hymn. Thus, from now on, the local Muses should not re-enact the original performance of the first performer, but this very best version, his own. The Delian Maidens do not need to inspire him, the best rhapsode, but they should, on the contrary, start now with a new chain of tradition. The new "original" derives from an anonymous blind man from Chios (172). In the seal the poetic "I" makes an indirect claim on

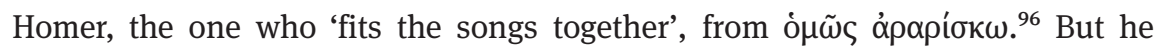
does not mention him explicitly. As a sort of new origin of the rhapsodic school of the Homeridae in Chios, he seals the tradition, implicitly giving it back to "Homer". From now on, the Delian Maidens can only re-enact this "Homeric" version. The shift to the "we" (174) implies that later rhapsodes of this school will from this point on only re-perform this very best epic song, our Homeric Hymn to Apollo. They will sing as if it came from the Delian Maidens, and the

96 See Nagy (2008/09) 206-8. 
future listeners will believe it, because it is the customary tradition to give it back to them as the local Muses. However, from this moment on they will only 'imitate' (see $\mu \mu \varepsilon \tilde{\sigma} \sigma \alpha \alpha$ 163) the voice of "Homer". The entire chain and diachronic

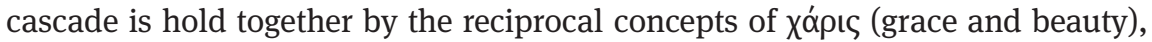
$\tau \dot{\varepsilon} \rho \psi ı \varsigma$ (pleasure) and $\theta \dot{\varepsilon} \lambda \xi ı \varsigma$ (enchantment). They also unify the performers and the audience in an almost divine experience of festive performativity. At last, behind everything Apollo, the origin and essence of song, comes to the fore in an unfolding epiphany of a hymn that continues.

The rhapsodic "I" cannot stop singing about Apollo, mediator of these amazing effects and emotions, and moves into the Pythian part (177-8). The god is addressed, pursuing his way from East to West, from Lycia, Miletus to the Delian festival, and finally to Delphi, where he is celebrated in choruses as well (179-85). The arrival of Apollo in Delphi will be the central theme of the second part of the Hymn. But, in the temporal order of events, the song starts from the end, how he leaves the earth from Delphi, arriving on Mount Olympus. The scene stands in parallel to the terrible arrival at the beginning of the Hymn, but also in contrast to it, because now it is not the bow, but the lyre that constitutes the at-

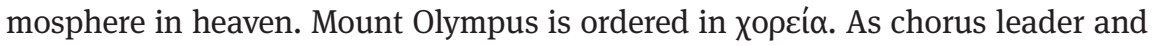
kitharodic singer, Apollo should be the centre, while the gods wish the arriving god to sing and play the lyre. The Muses respond in refrain, singing about the

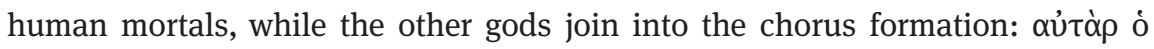

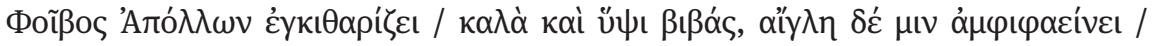

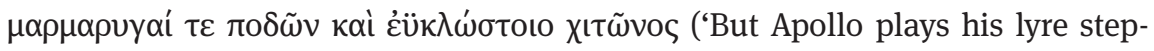
ping high and a radiance shines around him, the gleaming of his feet and close-woven mantle' 201-3). This scene carries again all features of an epiphany. The god of the bow evolved to the model of song, music and choral dance. ${ }^{97}$ From his choral competition in Delos he passed over Delphi and the choruses there to finally reach heaven and to establish the choral festivity among the Olympian gods.

Looping back from the end of the chronological order, the narration then focuses on Apollo's arrival in Delphi. Choosing his future attendants, he stages his epiphany in front of Cretan sailors. The scene full of wonder about his apparition as a dolphin on the ship, who leads it to land in Krisa (388-439), bears some traits of outdoing the Hymn to Dionysus. From there he guides the Cretans like

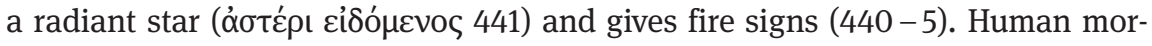
tals react to the epiphany with cries and fear (445-7). In a last step he appears now in the shape 'of a man, brisk and sturdy, in the prime of his youth, while his

97 See Bierl (2011) 137. 


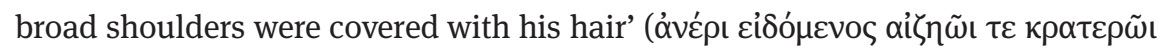

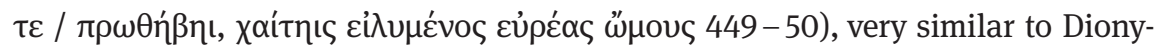

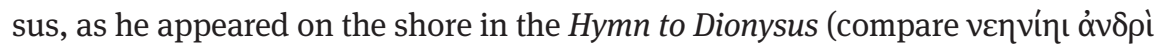

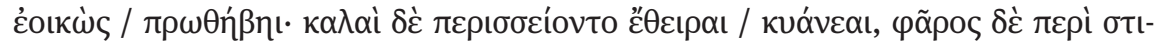

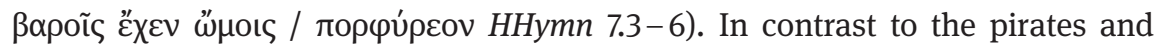
similar to the steersman in the Hymn to Dionysus, the leader of the sailors recognizes the god behind the young man (463-6) addressing a speech to them (451-61). The rhapsode finally tells how the god led his new band of attendants in a choral procession from the shore up to Delphi (514-23). As in the entrance scene at the beginning of the Pythian part (182-7, 201-3), 'Apollo, the son of Zeus, led them, holding a lyre in his hands, and playing sweetly as he stepped

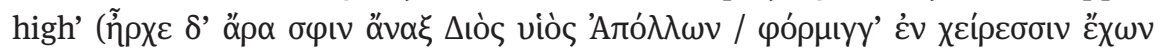

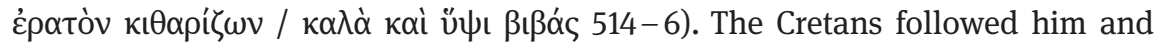
'chanted "Ie Paean" after the manner of the Cretan paean-singers and of those

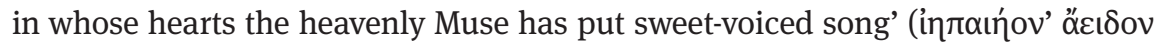

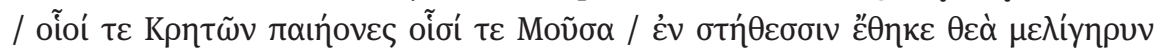
áoıঠ́v 517-19). This choral procession to Delphi is then the model for his choral entrance into the Olympus where he will order everything in choruses. On the one hand, in a loop, the impressive beginning of the Pythian part comes to mind (182-206, esp. 182-7, 201-3). On the other hand, moving backward in time, we are reminded of his birth, when he grabbed the lyre (131), and the time shortly afterwards, when Delian choruses were first institutionalised, which mirror Apollo's own chorality (146-64). In the final farewell (545) the god is summoned to take pleasure in this monumental song stitched together in artful loops and rings, itself comparable to the circular dance. In its very performance the original essence of the god comes to the fore. He becomes manifest and present, and by making mental contact with him, the persona cantans can call to mind another song (546). Perhaps the new song will be still another reperformance of this perfect composition done by 'the blind man' from Chios (181).

\section{Conclusion}

This paper has shown how Dionysus and Apollo, in their idiosyncratic manners which reflect their respective essences, became present through song and performance. In both cases the narration focuses on xopcí $\alpha$ in the making, on how both gods became gods linked to music, song and choral dance. The detailed epic narration makes this aspect of the Hymns all the more poignant and in this way brings the gods to mind, right before the reader's/listener's 
inner eyes, in all their glory. Therefore the song is the means to epiphanize the gods, while they themselves, in the inner story, become manifest through music, choral dance and other epiphanic strategies. The epic singer can thus self-referentially allude to his own epic production that itself unfolds in a poetic epiphany.

The Olympian gods can be grasped only in their anthropomorphic quality. Some are closer to men than others. Apollo is perhaps the least human of all. He is power in totality, full of energy, terrible force. Dionysus complements him, blurring the boundaries between men and animals. Through mystery cult

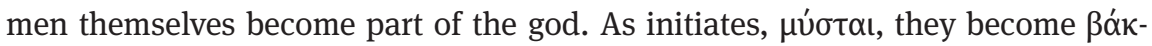

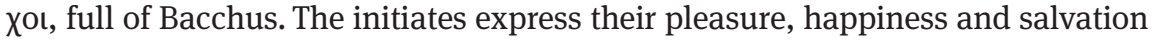
in choruses. As chorus leaders both gods have an effect on poetic production. In his choral and musical aspects Dionysus remains enigmatic, much more hidden, whereas Apollo is made present as an all-mighty force that dominates even the entire cosmos and the Olympus in chorality.

Perhaps it is not by chance that the Hymn to Hermes (HHymn 4) of a much later date, perhaps from the beginning of the fifth century $\mathrm{BC}$, comes next the Hymn to Apollo in the order of the collection. In this song Hermes, the closest god to men, invents the lyre, sings two songs (HHynm 4.54-62, 423-33), as mise en abyme and again in the dynamics of his epiphany, ${ }^{98}$ before giving it to Apollo in exchange for herds and numerous other honours. The vivid but mute tortoise must die to be transformed to the sounding instrument. The lyre is not just there, but must be fabricated. Song thus becomes much more artificial and detached from natural or even supernatural existence. The idea of an absolute origin is thus deconstructed and dissolved in traces that are blurred in the long tradition, just as Hermes blurs his footprints in the sand. In this new perspective it seems as if Apollo lost his original authenticity in respect to a living song culture and as if Hermes, as god of literacy, brought the diachronic chain of performances and re-performances to an end. ${ }^{99}$ But this is another story that must be developed elsewhere. This new view seems revolutionary, but even in the Hymn to Hermes the rhapsodic "I" attempts to connect with the god to make him present in song and to call him and new song in mind. In the same formulaic diction of the last line as given in the Hymn to Apollo (HHymn

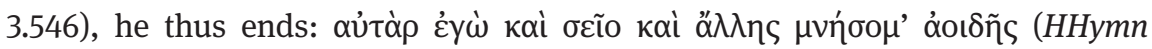
4.580). ${ }^{100}$

98 See Vergados (2013) 4-14. On the lyre, see Jaillard (2007) 167-96.

99 See Bergren (2008) 131-60.

100 I can only end by greeting Antonios Rengakos, the good colleague and friend: $\chi \alpha$ ĩp $\varepsilon$ - 'hail and take pleasure in that!' 


\section{Works cited}

Allen, W., W. R. Halliday, and E. E. Sikes (1936). The Homeric Hymns. Oxford.

Ausfeld, K. F. (1903). 'De Greaecorum precationibus quaestiones', Jahrbücher für classische Philologie 28: 503-47.

Bakker, E. (2005). Pointing at the Past: From Formula to Performance in Homeric Poetics. Cambridge, MA and London.

Bergren, A. (2008). Weaving Truth: Essays on Language and the Female in Greek Thought. Cambridge, MA and London.

Bierl, A. F. H. (1991). Dionysos und die griechische Tragödie. Politische und 'metatheatralische' Aspekte im Text. Tübingen.

-. (1999). 'Euripides, Bacchae. Edited with an Introduction, Translation and Commentary by Richard Seaford, Warminster 1996 (The Plays of Euripides)', Gnomon 71: 582-92.

-. (2004). “'Turn on the Light!” Epiphany, the God-Like Hero Odysseus, and the Golden Lamp of Athena in Homer's Odyssey (Especially 19.1-43)', ICS 29: 43-61.

-. (2007a). 'Literatur und Religion als Rito- und Mythopoetik: Überblicksartikel zu einem neuen Ansatz in der Klassischen Philologie', in: A. Bierl, R. Lämmle and K. Wesselmann (eds.), Literatur und Religion I. Wege zu einer mythisch-rituellen Poetik bei den Griechen. Berlin and New York, 1-76.

-. (2007b). 'Mnema und Mneme - Gedanken eines Gräzisten', in: H.-J. Lenger and G. C.

Tholen (eds.), Mnema. Derrida zum Andenken. Bielefeld, 47-64.

-. (2009). Ritual and Performativity. The Chorus in Old Comedy, translated by A. Hollmann. Cambridge, MA and London. http://nrs.harvard.edu/urn-3:hul.ebook:CHS_Bierl.Ritual_ and_Performativity.2009

-. (2011). 'Fest und Spiele in der griechischen Literatur', in: A. Chaniotis (ed.), Festivals and Contests (= ThesCRA VII). Los Angeles, 125-60.

-. (2012). 'Demodokos' Song of Ares and Aphrodite in Homer's Odyssey (8.266-366): An Epyllion? Agonistic Performativity and Cultural Metapoetics', in: M. Baumbach and S. Bär (eds.), Brill's Companion to Greek and Latin Epyllion and Its Reception. Leiden and Boston, 111-34.

-. (2013a). 'Dionysos in Old Comedy. Staging of Experiments on Myth and Cult', in: A. Bernabé et al. (eds.), Redefining Dionysos. Berlin and Boston, 366-85.

-. (2013b). 'Maenadism as Self-Referential Chorality in Euripides' Bacchae', in: R. Gagné and

M. G. Hopman (eds.), Choral Mediations in Greek Tragedy. Cambridge, 211-26.

-. (2015). 'New Trends in Homeric Scholarship (NTHS)', in: A. Bierl and J. Latacz (eds. / general editor of the English edition S. D. Olson), Homer's Iliad. The Basel Commentary (BKE), transl. by B.W. Millis and S. Strack, vol. I: Prolegomena. Berlin and Boston, $177-203$.

-. (2016). "'All you Need is Love”: Some Thoughts on the Structure, Texture, and Meaning of the Brothers Song as well as on Its Relation to the Kypris Song (P. Sapph. Obbink)', in: A. Bierl and A. Lardinois (eds.), The Newest Sappho (P. Sapph. Obbink and P. GC inv. 105, Frs. 1-4). Leiden, 302-36. open access online: http://booksandjournals.brillon line.com/content/books/9789004314832

Blech, M. (1982). Studien zum Kranz bei den Griechen. Berlin and New York.

Bohrer, K. H. (2015). Das Erscheinen des Dionysos. Antike Mythologie und moderne Metapher. Frankfurt am Mainz. 
Boisacq, E. (1916). Dictionnaire étymologique de la langue grecque. Heidelberg.

Bremer, D. (1975). 'Die Epiphanie des Gottes in den homerischen Hymnen und Platons Gottesbegriff', ZRGG 27: 1-21.

Burkert, W. (1979). 'Kynaithos, Polycrates and the Homeric Hymn to Apollo', in: G. W. Bowersock, W. Burkert and M. C. J. Putnam (eds.), Arktouros: Hellenic Studies Presented to B.M.W. Knox. Berlin, 53-62.

-. (1983). Homo Necans. The Anthropology of Ancient Greek Sacrificial Ritual and Myth, translated by P. Bing. Berkeley.

-. (1985). Greek Religion. Archaic and Classical, translated by J. Raffan. Cambridge, MA.

-. (1987). Ancient Mystery Cults. Cambridge, MA and London.

Calame, C. (2011). 'The Homeric Hymns as Poetic Offerings. Musical and Ritual Relationships with the Gods', in: Faulkner 2011b, 334-57.

Chantraine, P. (1968). Dictionnaire étymologique de la langue grecque. Histoire des mots. Paris.

Chappell, M. (2011). 'The Homeric Hymn to Apollo. The Question of Unity', in: Faulkner 2011b, $59-81$.

Clay, J. S. $\left(1989 / 2006^{2}\right)$. The Politics of Olympus: Form and Meaning in the Major Homeric Hymns. Princeton.

-. (2011). 'The Homeric Hymns as Genre', in: Faulkner 2011b, 232-53.

Csapo, E. (2003). 'The Dolphins of Dionysus', in: E. Csapo and M. C. Miller (eds.), Poetry, Theory, Praxis. The Social Life of Myth, Word and Image in Ancient Greece. Essays in Honour of William J. Slater. Oxford, 69-98.

-. (2008). 'Star Choruses: Eleusis, Orphism and New Musical Imagery and Dance', in: M. Revermann and P. Wilson (eds.), Performance, Iconography, Reception. Studies in Honour of Oliver Taplin. Oxford, 262-90.

Depew, M. (2000). 'Enacted and Represented Dedications: Genre and Greek Hymn', in: M. Depew and D. Obbink (eds.), Matrices of Genre: Authors, Canons, and Society. Cambridge, MA, 59-79.

Detienne, M. (1985). Dionysos à ciel ouvert. Paris.

Dietrich, B. C. (1983). 'Divine Epiphanies in Homer', Numen 30: 53-79.

Fernández Contreras, M. A. (1999). 'Las epifanías en la épica homérica', Habis 30: 7-17.

Faulkner, A. (2011a). 'Introduction. Modern Scholarship on the Homeric Hymns: Foundational Issues', in: Faulkner 2011b, 1-25.

-. (2011b). The Homeric Hymns. Interpretative Essays. Oxford.

Förstel, K. (1979). Untersuchungen zum Homerischen Apollonhymnos. Bochum.

Frisk, H. (1970). Griechisches etymologisches Wörterbuch, II. Heidelberg.

Foley, J. M. (1999). Homer's Traditional Art. University Park, PA.

Frame, D. (1978). The Myth of Return in Early Greek Epic. New Haven, CT. http://chs.harvard. edu/CHS/article/display/4317

Furley, W. D. (2011). 'Homeric and Un-Homeric Hexameter Hymns. A Question of Type', in: Faulkner 2011b, 206-231.

Furley, W. D. and J.M. Bremer (2001). Greek Hymns: Selected Cult Songs from the Archaic to the Hellenistic Period. I: The Texts in Translation; II: Greek Texts and Commentary. Tübingen.

García, J. F. (2002). 'Symbolic Action in the Homeric Hymns: The Theme of Recognition', ClAnt 21: 5-39. 
Gemoll, A. (1886). Die Homerischen Hymnen. Leipzig.

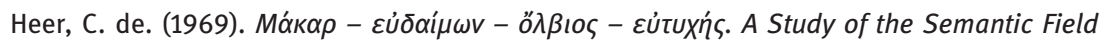
Denoting Happiness in Ancient Greek to the End of the 5th Century B.C. Amsterdam.

Henrichs, A. (1982). 'Changing Dionysiac Identities', in: B. F. Meyer and E. P. Sanders (eds.), Jewish and Christian Self-Definition, III. Self-Definition in the Graeco - Roman World. London, $137-60$ and 213-36.

-. (2011). 'Göttliche Präsenz als Differenz: Dionysos als epiphanischer Gott', in: R. Schlesier

(ed.), A Different God? Dionysos and Ancient Polytheism. Berlin and Boston, 105-16.

Herrero de Jáuregui, M. (2013). 'Dionysos in the Homeric Hymns: the Olympian Portrait of the God', in: A. Bernabé et al. (eds.), Redefining Dionysos. Berlin and Boston, 235-49.

-. (2016). “'Trust the God”: Tharsein in Ancient Greek Religion', HSPh 108: 1-52.

Humbert, J. (1936). Homère. Hymnes. Paris.

Jaillard, D. (2007). Configurations d'Hermès. Une 'théogonie hermaïque' (Kernos, supplément 17). Liège.

-. (2011). 'The Seventh Homeric Hymn to Dionysus', in: Faulkner 2011b, 133-50.

Joly, R. (1955). 'L'exhortation au courage (ӨAPPEIN) dans les mystères', REG 68: 164-70.

Lonsdale, S. H. (1993). Dance and Ritual Play in Greek Religion. Baltimore and London.

Martin, R. (2000). 'Synchronic Aspects of Homeric Performance: The Evidence of the Hymn to Apollo', in: A. González de Tobia (ed.), Una nueva visión de la cultura griega antigua hacia el fin del milenio. La Plata, 403-32.

Merkelbach, R. (1988). Die Hirten des Dionysos. Die Dionysos-Mysterien der römischen Kaiserzeit und der bukolische Roman des Longus. Stuttgart.

Miller, A. M. (1986). From Delos to Delphi: A Literary Study of the Homeric Hymn to Apollo. Leiden.

Montanari, F., A. Rengakos and C. Tsagalis (2012). Homeric Contexts. Neoanalysis and the Interpretation of Oral Poetry. Berlin and Boston.

Nagy, G. (1990a). Pindar's Homer. The Lyric Possession of an Epic Past. Baltimore and London. http://nrs.harvard.edu/urn-3:hul.ebook:CHS_Nagy.Pindars_Homer.1990

-. (1990b). Greek Mythology and Poetics. Ithaca NY and London. http://chs.harvard.edu/CHS/ article/display/5577

-. (1996). Poetry as Performance: Homer and Beyond. Cambridge.

-. (2003). Homeric Responses. Austin.

-. (2008/2009). Homer the Classic. Cambridge, MA and Washington, DC. http://nrs.harvard.edu/urn-3:hul.ebook:CHS_Nagy.Homer_the_Classic.2008

-. 2009/2010. Homer the Preclassic. Berkeley and Los Angeles.

http://nrs.harvard.edu/urn-3:hul.ebook:CHS_Nagy.Homer_the_Preclassic.2009

-. (2011). 'The Earliest Phases in the Reception of the Homeric Hymns', in: Faulkner 2011b, 280-333.

-. (2012). 'Signs of Hero Cult in Homeric Poetry', in: Montanari, Rengakos and Tsagalis 2012, 27-71.

-. (2013a). The Ancient Greek Hero in 24 Hours. Cambridge, MA and London. http://chs.har vard.edu/publications

-. (2013b). 'The Delian Maidens and Their Relevance to Choral Mimesis in Classical Drama', in: R. Gagné and M.G. Hopman (eds.), Choral Mediations in Greek Tragedy. Cambridge, $227-56$.

Nobili, C. (2009). 'L'Inno Omerico a Dioniso (Hymn. Hom. VII) e Corinto', ACME 62.3: 3-35. 
Olson, S. (2017). 'Kinesthetic Choreia: Empathy, Memory, and Dance in Ancient Greece', CP 112: $153-74$.

Otto, W. F. (1933/2011'). Dionysos. Mythos und Kultus. Frankfurt am Main.

Peponi, A.-E. (2009). 'Choreia and Aesthetics in the Homeric Hymn to Apollo: The Performance of the Delian Maidens (lines 156-64)', ClAnt 28: 39-70.

Petrovic, I. (2012). 'Rhapsodic Hymns and Epyllia', in: M. Baumbach and S. Bär (eds.), Brill's Companion to Greek and Latin Epyllion and its Reception, Leiden and Boston, 149-76.

Pfister, F. 1924. “Epiphanie”, RE Suppl. IV: 277-323.

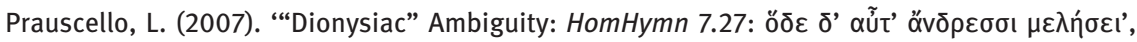
MD 58: 209-216.

Rengakos, A. (2002). 'Narrativität, Intertextualität, Selbstreferentialität. Die neue Deutung der Odyssee', in: M. Reichel and A. Rengakos (eds.), EPEA PTEROENTA. Beiträge zur Homerforschung. Festschrift für Wolfgang Kullmann zum 75. Geburtstag. Stuttgart, $173-91$.

Richardson, N. J. (1974). The Homeric Hymn to Demeter. Oxford.

Ruhnken, D. (1749). Epistola critica I. In Homeridarum Hymnos et Hesiodum, ad L. C. Valckenarium. Leiden.

Seaford, R. (1981). 'Dionysiac Drama and the Dionysiac Mysteries', CQ 31: 252-75.

-. (1996). Euripides. Bacchae, with an Introduction, Translation and Commentary. Warminster.

Stehle, E. (1996). Performance and Gender in Ancient Greece. Nondramatic Poetry in Its Setting. Princeton.

Tsagalis, C. (2008). The Oral Palimpsest. Exploring Intertextuality in the Homeric Epics. Cambridge, MA and London.

-. (2011). 'Towards an Oral, Intertextual Neoanalysis', TC 3: 209-44.

Turkeltaub, D. W. (2003). The Gods' Radiance Manifest: An Examination of the Narrative Pattern Underlying the Homeric Divine Epiphany Scenes. Diss., Cornell.

Vergados, A. (2011). 'The Homeric Hymn to Hermes: Humour and Epiphany', in: Faulkner 2011b, 82-104.

-. (2013). The Homeric Hymn to Hermes: Introduction, Text and Commentary. Berlin and Boston.

Vernant, J.-P. (1988). 'Aspects mythiques de la mémoire', in: id. (ed.), Mythe et pensée chez les Grecs. Études de psychologie historique. Paris, 109-36.

Versnel, H. S. (1993). Inconsistencies in Greek and Roman Religion II. Transition and Reversal in Myth and Ritual. Leiden.

-. (2011). Coping with the Gods: Wayward Readings in Greek Theology. Leiden and Boston.

West, M. L. (1975). 'Cynaethus' Hymn to Apollo', CQ 25: 161-70.

Wilamowitz-Moellendorff, U. von (1916). Die Ilias und Homer. Berlin.

Wildberg, C. (2002). Hyperesie und Epiphanie. Ein Versuch über die Bedeutung der Götter in den Dramen des Euripides. Munich.

Wolf, F. A. (1795/1985). Prolegomena ad Homerum sive de operum Homericorum prisca et genuina forma variisque mutationibus et probabili ratione emendandi. Halle; cited after the adnotated English translation: Prolegomena to Homer. Translated with Introduction and Notes, eds. A. Grafton, G. W. Most, and J. E. G. Zetzel. Princeton. 
Brought to you by | Universitaetsbibliothek Basel

Authenticated Download Date | 1/24/18 3:04 PM 